See discussions, stats, and author profiles for this publication at: https://www.researchgate.net/publication/331286364

\title{
3D litho-constrained inversion model of southern Sierra Grande de San Luis: new insights into the Famatinian tectonic setting
}

Preprint $\cdot$ February 2019

CITATIONS

0

8 authors, including:

IIII

Rodolfo Christiansen

Ruhr-Universität Bochum (Alexander von Humboldt Foundation)

35 PUBLICATIONS 52 CITATIONS

SEE PROFILE

Federico Lince Klinger

National University of San Juan

73 PUBLICATIONS 316 CITATIONS

SEE PROFILE
READS

442

Augusto Morosini

Universidad Nacional de San Luis

30 PUBLICATIONS 93 CITATIONS

SEE PROFILE

Myriam Patricia Martinez

National University of San Juan

175 PUBLICATIONS 880 CITATIONS

SEE PROFILE

Some of the authors of this publication are also working on these related projects:

1.- Proyecto La Planicie 2.- Cuenca de Alvear, La Pampa 3.- Batolito Loma Alta, La Pampa View project

Low-Cost and Simple Arduino-Based Educational Labs for Physics 1 View project 


\section{Accepted Manuscript}

3D litho-constrained inversion model of southern Sierra Grande de San Luis: New insights into the Famatinian tectonic setting

Rodolfo Christiansen, Augusto Morosini, Eliel Enriquez, Brian Muñoz, Federico Lince Klinger, Myriam P. Martinez, Ariel Ortiz Suárez, José Kostadinoff

PII: $\quad$ S0040-1951(19)30060-5

DOI: $\quad$ https://doi.org/10.1016/j.tecto.2019.02.015

Reference: $\quad$ TECTO 128049

To appear in: $\quad$ Tectonophysics

Received date: $\quad 3$ October 2018

Revised date: $\quad 20$ February 2019

Accepted date: $\quad 22$ February 2019

Please cite this article as: R. Christiansen, A. Morosini, E. Enriquez, et al., 3D lithoconstrained inversion model of southern Sierra Grande de San Luis: New insights into the Famatinian tectonic setting, Tectonophysics, https://doi.org/10.1016/j.tecto.2019.02.015

This is a PDF file of an unedited manuscript that has been accepted for publication. As a service to our customers we are providing this early version of the manuscript. The manuscript will undergo copyediting, typesetting, and review of the resulting proof before it is published in its final form. Please note that during the production process errors may be discovered which could affect the content, and all legal disclaimers that apply to the journal pertain. 


\section{D litho-constrained inversion model of southern Sierra Grande de San}

\section{Luis: new insights into the Famatinian tectonic setting}

Rodolfo Christiansen ${ }^{1,2^{*}}$, Augusto Morosini ${ }^{3,4}$, Eliel Enriquez ${ }^{3,4}$, Brian Muñoz ${ }^{3}$, Federico Lince Klinger $^{1}$, Myriam P. Martinez ${ }^{1,2}$, Ariel Ortiz Suárez ${ }^{4}$, José Kostadinoff ${ }^{5}$

${ }^{1}$ IGSV - CONICET - UNSJ - San Juan, Argentina

${ }^{2}$ Departamento de Geofísica - UNSJ - San Juan, Argentina

${ }^{3}$ CCT - CONICET - San Luis, Argentina

${ }^{4}$ Departamento de Geología - UNSL - San Luis, Argentina

${ }^{5}$ Departamento de Física - UNS- Bahía Blanca, Argentina

*Corresponding author

E-mail: rodolfo.christiansen@conicet.gov.ar

Instituto Geofísico Sismológico Volponi - Universidad Nacional de San Juan

Ruta 12 - km 17. Marquesado, San Juan, Argentina. CP 5407

Phone / Fax: +54 92644945015 


\begin{abstract}
Unravelling the orogenic structure of the Sierra Grande de San Luis (Argentina) is essential to understand the geological evolution of the Famatinian orogen and the western margin of Gondwana. However, its structural organization is still poorly known and widely debated. In this contribution, a new interpretation of the complex geological structures in the southern sector of the Sierra Grande de San Luis is presented. This work is based on a lithoconstrained joint inversion of gravity and magnetic datasets combining lithological, structural and rock properties information. Results are consistent with a large-scale doubly-vergent structure caused by a compressional tectonic setting as a consequence of the collision between an allochthonous terrane (Cuyania/Precordillera) and the proto margin of Western Gondwana. A convex morphology of the indenter is proposed to be responsible for producing a significant clockwise rotation of the horizontal deviatoric stresses. This stress field caused a small sinistral component of movement and gave rise to the doubly-vergent transpressive mega-structure.
\end{abstract}

Keywords: Inversion model, doubly-vergent structure, Sierra Grande de San Luis, Famatinian collision, Western Gondwana 


\section{Introduction}

Considered as an excellent example of paleo-collisional environments, the Sierra Grande de San Luis (SGSL) has been a major topic of study because of its connections with the development of the western margin of Gondwana. On the basis of surface structural data, analysis of metamorphism and magmatism, and absolute age data, several tectonic evolution models were proposed for the southern area of the SGSL (e.g. Siegesmund et al., 2004; von Gosen and Prozzi, 2005; Steenken et al., 2008; Drobe et al., 2009, among others). The most accepted idea is that the internal basement structures were developed during the Famatinian orogeny (Ortiz Suárez et al., 1992; Sims et al., 1997; von Gosen, 1998a; Sato et al., 2003) product of the collision between the Laurentian-derived (Thomas and Astini, 1996) Cuyania/Precordillera terrane (Whitmeyer and Simpson, 2004; von Gosen and Prozzi, 2005) and the western margin of Gondwana (Rapela et al., 2001; Otamendi et al., 2009; Steenken et al., 2010) from the Middle-Late Ordovician (Thomas and Astini, 2003; Ramos, 2004). More importantly, there is no agreement regarding the orogenic architecture resulting from the Early Paleozoic deformational events. According to the different authors, the southern area of the SGSL would be the core of a regional-scale antiform (Sims et al., 1997, 1998; Whitmeyer and Simpson, 2004), a transpressional structure (von Gosen and Prozzi, 1998) associated with a conjugate shear system (von Gosen and Prozzi, 2005), a large-scale transpressional positive flower structure (Morosini et al., 2014), or a mega-shear zone (Delpino et al., 2016).

A major limitation on all the current tectonic evolution interpretations is the lack of knowledge of the structures at depth since 3D geological models have not supported them. In this sense, gravity and magnetic provide information about the characteristics of the crust only by surface data processing (Oldenburg et al., 2007). The robustness of the model will depend on the data distribution, the inversion technique and the amount of information collected (density, magnetic susceptibility, structural data and other available constraints). In this work, we integrate geological and geophysical data into a 3D litho-constrained inversion model to understand better the orogenic architecture of the Famatinian orogen. The interpretation of these results provides useful insights into the geological structures of southern SGSL, the tectonic evolution of the Famatinian orogen and the construction of the western margin of Gondwana. 


\section{Geological setting}

Located in the southern sector of Sierras Pampeanas (Caminos, 1979), the Sierra Grande de San Luis has a general NE trend with an extension of approximately $160 \mathrm{~km}$ long and $80 \mathrm{~km}$ wide (Fig. 1). Three principal NNE trending metamorphic complexes, called Nogolí (NMC), Pringles (PMC), and Conlara (CMC) (Sims et al., 1997), dominate it. Two narrow low-grade metamorphic belts, named San Luis Formation (SLF) by Prozzi and Ramos (1988), separate these units. The tectonic nature of the contacts between the metamorphic units is indicated by the presence of many ductile shear zones that are parallel to subparallel to the main regional metamorphic NNE foliation (von Gosen and Prozzi, 2005). These shear zones produce the superposition of high-grade metamorphic rocks over medium and lowgrade metamorphic rocks, resulting in an inverted metamorphism structure (Ortiz Suárez and Casquet, 2005).

The Nogolí Metamorphic Complex is composed of paragneisses, orthogneisses, migmatites, schists, orthoamphibolites, marble, calc-silicate rocks and banded iron layers (Ortiz Suárez, 1999; González et al., 2004). According to its deformation, two structural sets can be recognized within this complex: one is a relict NW foliation attributed to preFamatinian events and the other is a penetrative NNE foliation, which was assigned to Famatinian events (Sato et al., 2003). Ages of 470 to $445 \mathrm{Ma}$ (obtained by CHIME U/Th/Pb monazite and Sm/Nd mineral-wall rock isochron) in gneisses, 476 to $457 \mathrm{Ma}$ ( $\mathrm{Ar} / \mathrm{Ar}$ and $\mathrm{K} / \mathrm{Ar}$ in amphibole) in amphibolites (González et al., 2004) and $478 \pm 4 \mathrm{Ma}$ (SHRIMP U/Pbmonazite) in metapsammopelites (Steenken et al., 2006), suggest an Ordovician metamorphism age (Famatinian) for this complex. The maximum sedimentation age of the protoliths has been defined at $\sim 530 \mathrm{Ma}$ by $\mathrm{U} / \mathrm{Pb}$ in detrital zircon (Drobe et al., 2009).

The Pringles Metamorphic Complex includes two units. One is a mid-grade metamorphic unit called Micaschist Group (MG) (von Gosen and Prozzi, 1998). The other one is a high-grade metamorphic unit which reaches granulite facies (Hauzenberger et al., 2001; Delpino et al., 2001; Ortiz Suárez and Casquet, 2005; Delpino et al., 2016) named San José Complex (SJC) (Costa et al., 2001a). The Micaschist Group consists predominantly of muscovite-biotite schists alternating with meta-quartzites. Pegmatitic injections are locally important, especially around synorogenic granitoids (Ortiz Suárez et al., 1992). This unit is placed between the San José Complex and both belts of the San Luis Formation, whose sedimentary protoliths probably belongs to the same clastic sequence (Hauzenberger et al., 
2001). In this area, the Micaschist Group represents intermediate crustal portions (Morosini et al., 2014). The high-grade unit is principally composed of migmatites and paragneisses, and to a lesser extent, of amphibolites, granulites, orthogneisses and calc-silicate rocks. The La Jovita-Las Águilas mafic-ultramafic Complex (Sato et al., 2003) is hosted in the San José Complex and is spatially related to an internal mylonitic zone called La Arenilla (Ortiz Suárez et al., 1992). The age of metamorphism of the Pringles Metamorphic Complex has been defined from $498 \pm 10 \mathrm{Ma}$ (SHRIMP U/Pb-zircon) in granulites, to $452 \pm 19 \mathrm{Ma}$ (stepwise leaching $\mathrm{Pb} / \mathrm{Pb}$-garnet) in gneisses (Steenken et al., 2006). Sims et al. (1998) defined a metamorphic climax between 460-450 Ma, through SHRIMP U/Pb-zircon and monazite method in gneisses. The maximum age of the sedimentary protoliths is $~ 530 \mathrm{Ma}$, with provenance from a Pampean source (Sims et al., 1998; Steeken et al., 2006).

The Conlara Metamorphic Complex comprises high to mid-grade metamorphic rocks. It is mostly composed of gneisses, migmatites, banded schists, orthoamphibolites and to a lesser extent by marbles and calc-silicate rocks (Llambías and Malvicini, 1982; Delakowitz et al., 1991; López de Luchi et al., 2003). Three deformational phases (Ortiz Suárez, 1988) with two folding stages (von Gosen and Prozzi, 1998) were recognized for this unit. Siegesmund et al. (2010) determined an Ediacaran age of $564 \pm 21 \mathrm{Ma}$ (stepwise leaching $\mathrm{Pb} / \mathrm{Pb}$-garnet) while Whitmeyer and Simpson (2004) published Famatinian ages of 482 to $470 \mathrm{Ma}(\mathrm{U} / \mathrm{Pb}-$ monazite) for the metamorphism. The maximum depositional ages of the sedimentary protoliths have been defined at 580 Ma (Drobe et al., 2009) and 550 Ma (Rapela et al., 2015).

The San Luis Formation is composed of metapelites (phyllites and shales), metasandstones, metaconglomerates and acid metavolcanic rocks affected by greenschist facies (low-grade) metamorphism (Prozzi and Ramos, 1988; von Gosen, 1998b). Tight and asymmetrical folds with a slight vergence towards the east (von Gosen, 1998b; Ortiz Suarez, 1999) characterize the structure. The sedimentary protolith of the San Luis Formation can interpreted as belonging to a turbiditic sequence (Zavala et al., 2000) of a foreland basin (Chernicoff and Ramos, 2003) formed predominantly by felsic recycled materials (López de Luchi et al., 2003). The metamorphism has occurred after the intrusion of metavolcanic rocks dated in $470 \mathrm{Ma}$ (Casquet et al., 2014). The maximum sedimentation age has been determined at $\sim 510 \mathrm{Ma}$, from a Pampean source by detrital zircon (Drobe et al., 2011). 
Two groups of plutonic magmatism in the SGSL have been extensively studied in the last three decades (Ortiz Suárez et al., 1992; Llambías et al., 1998; Sims et al., 1998; Sato et al., 2003; López de Luchi et al., 2007; among others). The first group is a CambroOrdovician orogenic magmatism, associated with the development of the Famatinian arc. The second group is a Devonian post-orogenic magmatism, which is associated with a stage of erosion and post-collisional ascent during the Achalian orogeny (Fig. 1b, Morosini et al., 2017 and references therein). Cambro-Ordovician orogenic plutonic magmatism is composed of basic-ultrabasic (gabbros, hornblendites, pyroxenites and peridotites), intermediate (diorites and tonalites), and acidic rocks (granodiorites, granites, pegmatites and metavulcanites). Devonian post-orogenic magmatism is characterized by the development of large monzogranitic and monzonitic plutons (greater than $30 \mathrm{~km}^{2}$ ). These plutons associated to an episode of crustal growth by enriched mantle derived magma input and variable degrees of partial melting of a lower crustal source at the waning stages (López de Luchi et al., 2007, 2017; and references therein). 


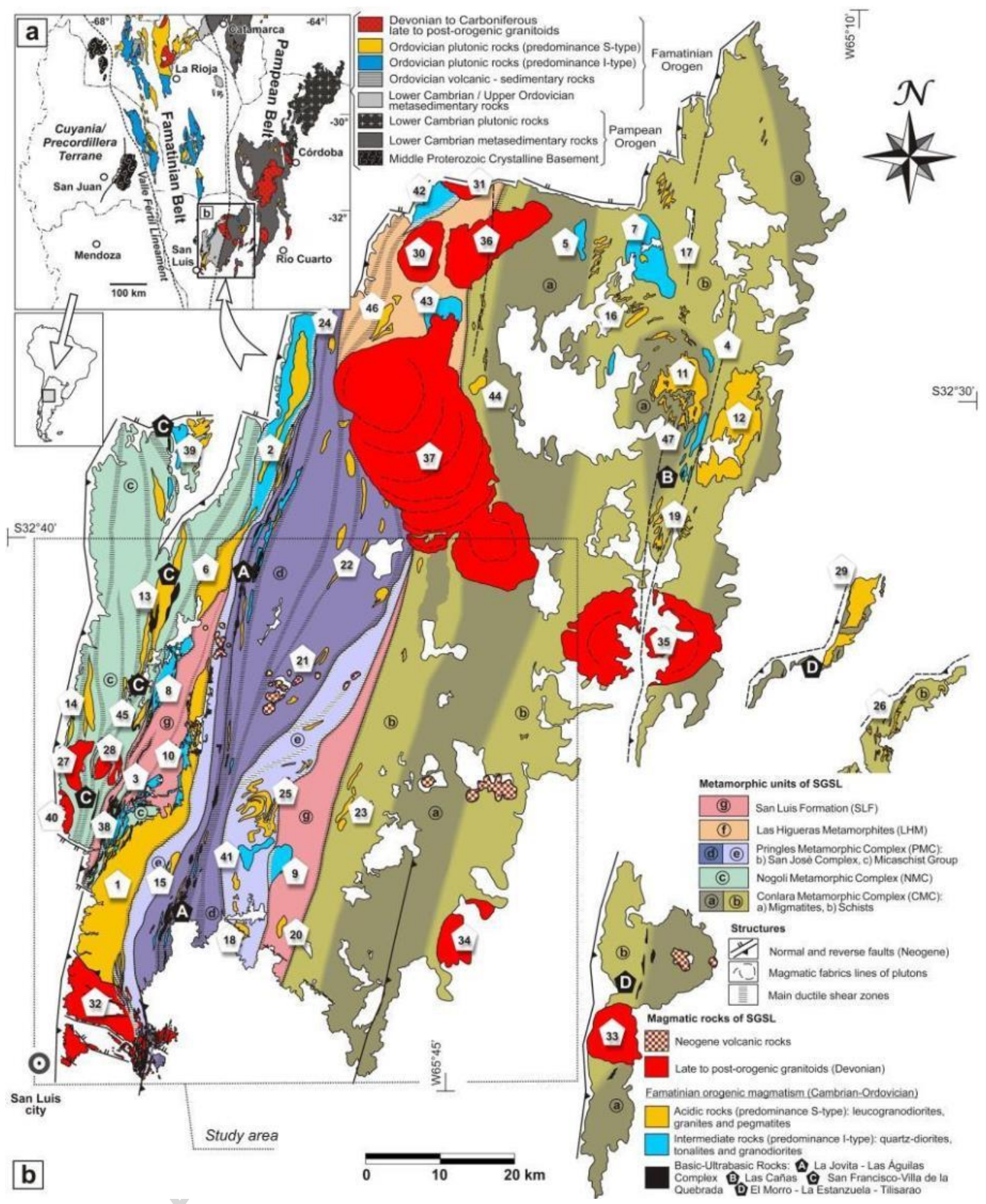

Fig. 1: a) Map showing the location of the SGSL in the context of the Pampean orogen, Famatinian magmatic arc, and the Cuyania/Precordillera terrane. b) Geological map of the SGSL showing the distribution of metamorphic and magmatic units. The black dotted line box represents the location of the inversion model. Numbers correspond to the plutons: 1) La Escalerilla, 2) El Realito, 3) Bemberg, 4) El Salado, 5) Las Cienaguitas, 6) San Miguel, 7) Rodeo, 8) Gasparillo, 9) Tamboreo, 10) Las Verbenas-El Salto, 11) Los Alanices, 12) El Peñón, 13) Río Claro, 14) Pantanos Negros, 15) Manantiales, 16) La Ciénaga, 17) La Represa, 18) La Florida, 19) La Tapera, 20) Río Quinto, 21) Cerros Largos, 22) Cruz de Caña, 23) Río de la Carpa, 24) Río Luján, 25) Paso del Rey, 26) El Tala, 27) El Molle, 28) Barroso, 29) Tilisarao, 30) El Telarillo, 31) La Población, 32) El Volcán, 33) El Morro, 34) La Totora, 35) Renca, 36) El Hornito, 37) Las Chacras-Potrerillo, 38) Tinaja, 39) Socoscora, 40) Villa de la Quebrada, 41) La Bajada, 42) Quines, 43) Puesto Las Palmas, 44) Don Andino, 45) La Barranquita, 46) Quebrada Escondida (modified from Morosini et al., 2017). 
During the continent-arc collision, deformation reached all crustal levels through different mechanisms: 1) Large scale fold and thrust belts in the upper Famatinian crust (Astini and Dávila, 2004; Cristofolini et al., 2014); 2) strike-slip movement along major shear zones in the front and margins of the Famatinian orogen (von Gosen and Prozzi, 1998, 2005; Höckenreiner et al., 2003); 3) large-scale west-verging shear zones located in the already crystalline Pampean basement (Sims et al., 1997; Martino, 2003; Cristofolini et al., 2017; Semenov and Weinberg, 2017); and 4) double-vergent ductile deformation belts (Larrovere et al., 2016) located at different sites within the collisional arc. The most important structural feature in the area is the San Luis Shear System (von Gosen and Prozzi, 2005). It has a general NNE trend and usually shows curved surfaces and associated structures (e.g. synthetic and secondary shear faults).

The current exposure of the metamorphic units occurred from the Middle Permian, while the main cooling/exhumation phases took place during the Triassic/Early Jurassic with no significant exhumation after Cretaceous times (Bense et al., 2017). Neogene deformation occurred due to a reverse fault system (located on the western side of the SGSL) with N trend and variable dip to the east. Normal and strike-slip faults with different orientations associated with the main inverse system are also recognized (Costa et al., 2001a). In addition, a Miocene-Pliocene magmatic episode was linked to the Pampean flat-slab, where the eastward migration of the Andean magmatic arc occurred (Ramos et al., 2002). This migration occurred due to the flattening of the Nazca plate after the subduction of the Juan Fernandez aseismic ridge (Barazangi and Isacks, 1976; Gutscher et al., 2000; among others). The associated magmatism is characterized by the development of volcanic domes and eruptive lithofacies. This unit is arranged along a WNW stripe, with strong structural control of the pre-Andean crust and conjugated fracture systems (Sruoga et al., 2017).

Geophysical studies in the Sierra Grande de San Luis are scarce. In an attempt to understand the mafic-ultramafic intrusions in southern SGSL, Kostadinoff et al. (1998) computed the first forward 2D models estimating a mafic-ultramafic intrusion of about 250 $\mathrm{km}^{3}$. Zaffarana et al. (2011) demonstrated that most of the gravity anomaly centred in the SGSL could be explained by the lateral contrast between the high-grade metamorphic complex that hosts the mafic-ultramafic rocks and the surrounding less dense metamorphic units. In addition, they showed that it does not require appealing to near-surface maficultramafic bodies larger than the size observed in surface outcrops. However, these models were very limited as for the area covered and they did not take into account variations in density and magnetic susceptibility within the same geological units. The latest large-scale 
geophysical studies correspond to Chernicoff and Ramos (2003) who not only analysed the aeromagnetic maps of the Sierra de San Luis and Comechingones but also defined "lithomagnetic" units. These units are differentiated by having a uniform magnetic signal and are limited by the presence of faults and/or fractures.

In this manuscript, new detailed data of the structures of southern SGSL are presented. This new information is an essential component in the development of more robust and modern geological models obtained by litho-constrained inversion of geological and geophysical datasets. These models show the continuation of the structures at depth and how is the distribution of rock properties (density and magnetic susceptibility) in the geological units. In this way, the units are described not only based on their litho-magnetic signature over the surface, but also as likelihood statistics in the entire study area in three dimensions.

\section{Methods and data}

\subsection{Geological and structural data}

Geological and structural data are essential components of the litho-constrained models. In this sense, cartography was produced with the support of LANDSAT, ASTER and Google Earth satellite images, through a geodatabase in the Qgis software. The lithological units were recognized and hand samples were collected to be studied through routine petrographic analysis. Structural data (mylonitic foliations, stretching lineations, fold axes, kinematic criteria, etc.) were acquired along transversal profiles to the main shear zones, which generally limit the metamorphic units (Fig. 2). Collected data were plotted and processed statistically with Stereonet 2011-2015 (Allmendinger et al., 2013; Cardozo and Allmendinger, 2013). The structural data sets, along with some characteristics previously published by other authors are shown in Table 1. Photographs of the main structural features are presented in Figure 3. 


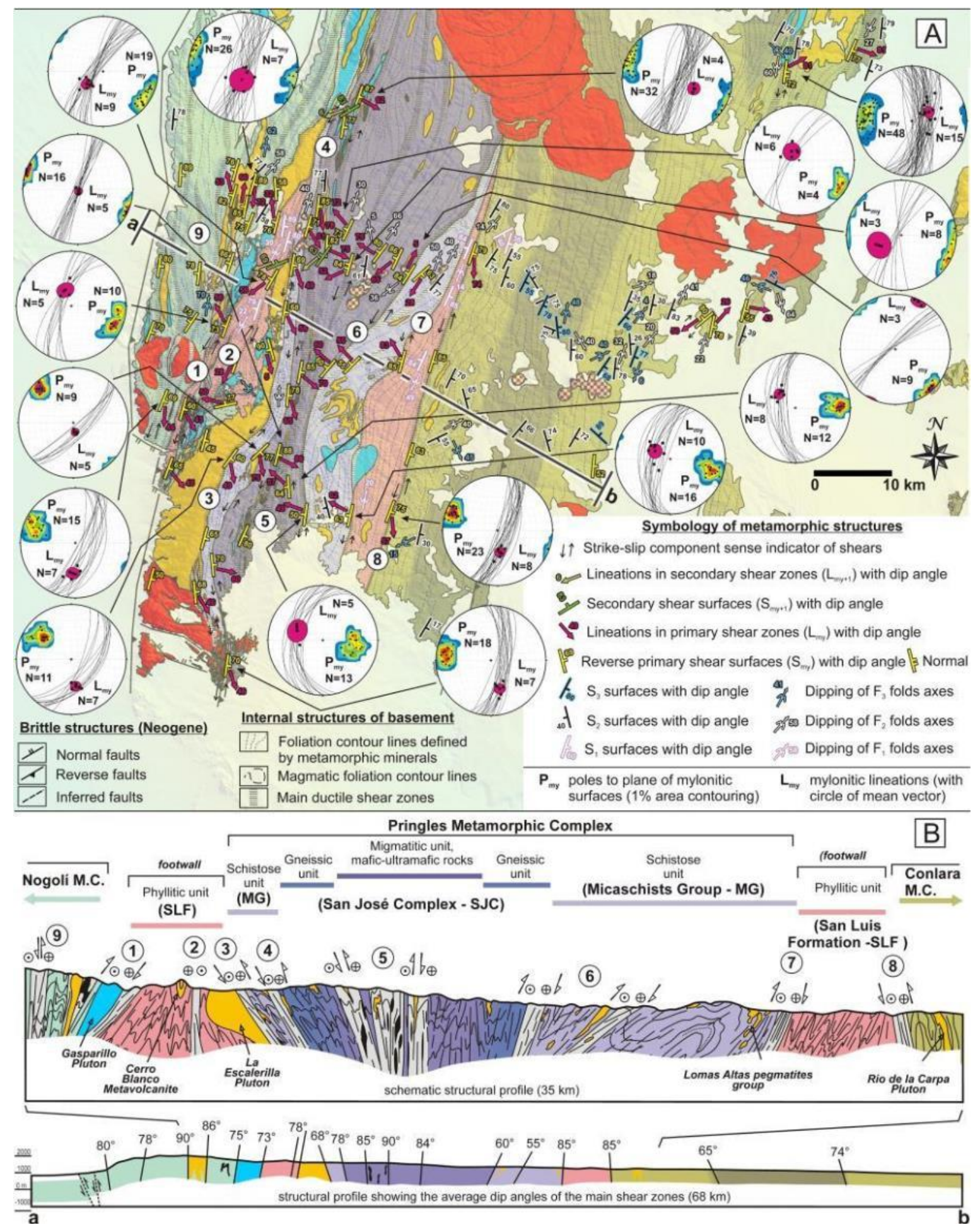

Fig. 2: Structural results for the study area. A) Plot of the internal structures of the basement. The poles to plane represent mylonitic foliations $\left(\mathrm{P}_{\mathrm{my}}\right)$, and $\mathrm{L}_{\mathrm{my}}$ represent the mylonitic stretching lineations of the main shear zones in the southern area of the SGSL. B) Schematic structural profile of the Pringles Metamorphic Complex and the San Luis Formation according to the projected surface data. Numbers represent the main shear zones: 1) El Realito-Río de la Quebrada, 2) Pancanta-La Carolina, 3) La Escalerilla, 4) San Pedro-El Volcán, 5) La Arenilla, 6) La Troya, 7) Ciénaga de Inti Huasi, 8) Río Guzmán, 9) Río Los Bayos - Funes, and others of the Nogolí Metamorphic Complex (undifferentiated). The shear zones are dominantly reverse and define a transpressional double-vergent structure with top-to-west on the west and top-to-east on the east, and have a minor sinistral strike-slip component. The mafic-ultramafic sequence lies in the core of the double-vergent structure. 

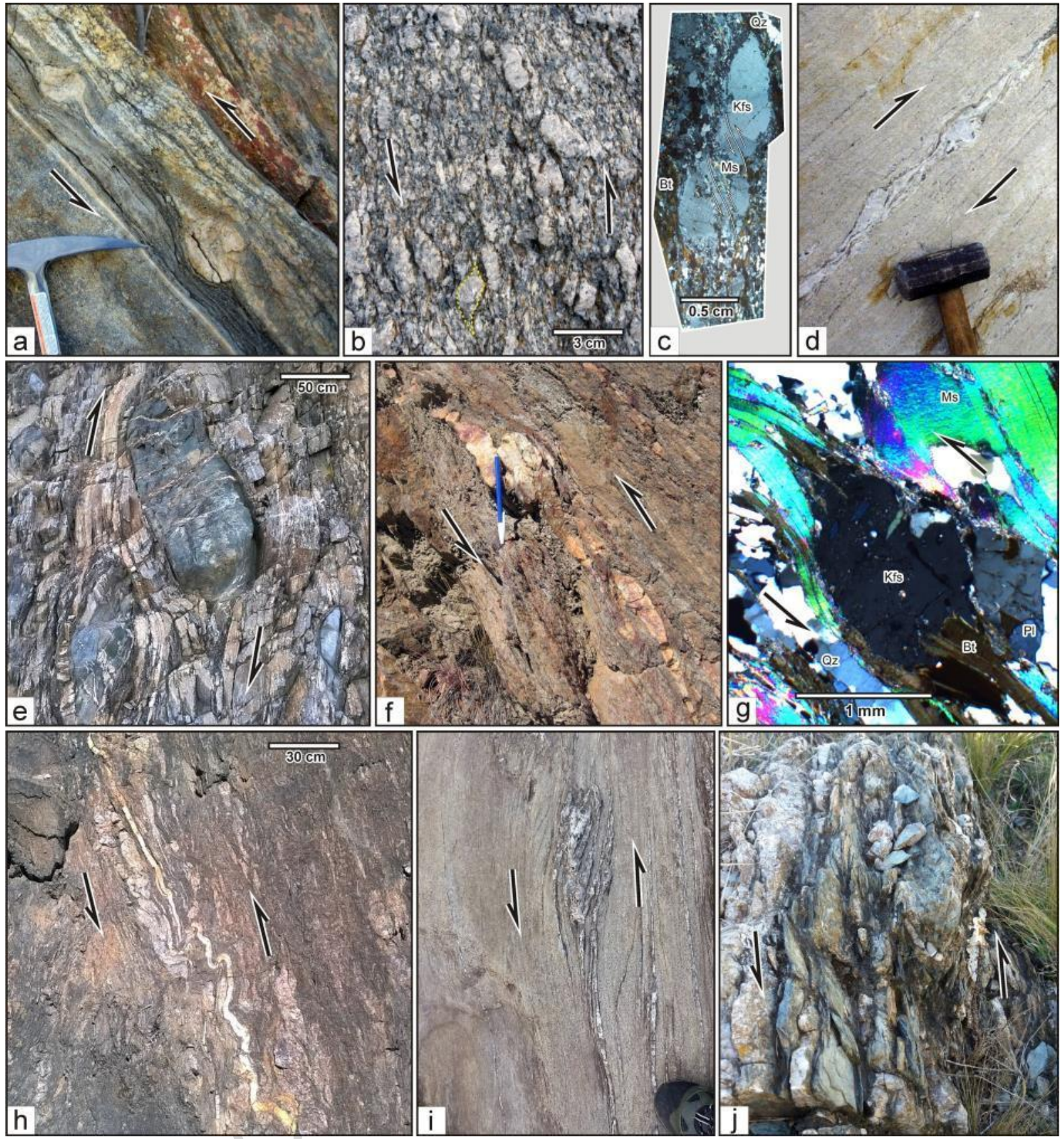

Fig. 3: Examples of the main shear zones (SZ) exposed in the central area of the SGSL. a) $\delta$-shape clasts in the southern part of the El Realito-Río de la Quebrada SZ (vertical view and reverse sense). b) Granite mylonite within a synthetic branch of the La Escalerilla SZ (horizontal view with a sinistral shear sense). c) Imbricated Kfeldspar porphyroclast with recrystallized "tails" and intracrystalline microfractures of the granite mylonite shown in b (thin section image under crossed polars). d) Pinch and swell structure of K-feldspar and quartz in aplo-pegmatitic mylonites of the San Pedro-El Volcán SZ (vertical view and reverse sense). e) Sigmoidal boudins of amphibolite rocks (up to $1 \mathrm{~m}$ thick) wrapped by mylonitic para-derived migmatites. High-angle reverse movement (east over west) in this site of the La Arenilla SZ is observed (vertical view and reverse sense). f) Asymmetric folds of felsic segregations in a gneiss (San José Complex - PMC) indicating a reverse movement component (west over east) in the La Troya SZ (vertical view and reverse sense). g) $\sigma$-type porphyroclast (Kfs) in a mylonitic gneiss corresponding to the La Troya SZ (thin section image under crossed polars). h) Asymmetric folds of felsic segregations in micaceous schists (Micaschist Group) indicating a reverse movement component (west over east) in the Inti Huasi SZ (vertical view and reverse sense). i) Phyllonites within the San Luis Formation in the Inti Huasi SZ. Asymmetrical folds that indicate oblique sinistral sense are shown (horizontal view with a sinistral shear sense). j) Phyllonites on the Río Guzmán SZ (view tilted to the north and reverse sense with sinistral strike-slip component). 


\subsection{Gravity data}

In order to suppress the border effects and to have a regional context of the long wavelength anomalies, 886 gravity stations (260 correspond to the modelled area) were used to compute the Bouguer anomaly covering the entire SGSL area. The theoretical gravity was calculated using the International Gravity Formula 1967. Bouguer gravity anomalies (Blakely, 1995) were calculated considering an average rock density of $2.67 \mathrm{~g} / \mathrm{cm}^{3}$ (Hinze, 2003). Anomaly values were corrected for earth curvature (LaFehr, 1991a, b). Terrain effects were subtracted by a combination of the method described by Nagy (1966) and Kane (1962) using local and regional DEMs with $90 \mathrm{~m}$ and $300 \mathrm{~m}$ resolutions respectively and a terrain density of $2.67 \mathrm{~g} / \mathrm{cm}^{3}$. The anomaly map was obtained utilizing kriging interpolation with a $1500 \mathrm{~m}$ cell size (Christiansen et al., 2015).

Assuming that the residual anomalies are caused only by shallow and intra-basement gravity sources a regional-residual separation was performed obtaining the Residual Bouguer Anomaly map (Fig. 4a). This method consists of cross-correlating grids of two successive upward continuation heights finding the maximum deflection of these cross correlation values (Zeng et al., 2007). The obtained upward continuation height was $25 \mathrm{~km}$ that corresponds to a maximum research depth of approximately $6 \mathrm{~km}$ (Jacobsen, 1987). Once the process is applied, the lateral density contrasts that tend to be associated with intrusions or changes in lithology in the upper crust can be interpreted.

\subsection{Magnetic data}

The Total Magnetic Anomaly (TMA) grid belongs to Area 1 Servicio Geológico Minero Argentino (SEGEMAR). It was acquired at a nominal height of $120 \mathrm{~m}$ along E-W lines spaced every $500 \mathrm{~m}$ with N-S tie lines every $5000 \mathrm{~m}$. A non-linear filter (Naudy and Dreyer, 1968) was used to remove data spikes (high amplitude and short wavelength noise) and then the resultant data were gridded to a cell size of $160 \mathrm{~m}$ utilizing a bi-directional gridding method. The residual TMA grid (Fig. 4b) was obtained applying a Gaussian filter with a cut-off wavelength of $24 \mathrm{~km}$ for a maximum depth of investigation of approximately 6 $\mathrm{km}$. This number was calculated assuming anomalies from concentrated sources (e.g. spherical) at a depth $\mathrm{z}$ to its centre and following the half-width rule. This formula establishes that the relationship between the depth of investigation and the cut-off wavelength $(\lambda)$ is $\lambda \geq$ $4 \times z$. 


\subsection{Density and magnetic susceptibility data}

Rock samples were collected (Fig. 4a and 4c) to measure density values in the laboratory (272 samples, Table 2) based on the method of double weighing with paraffin (Smithson, 1971). The magnetic susceptibility of the different units (345 values, Table 3) were measured on site with a magnetic susceptibility meter averaging at least five measurements within a radius of $50 \mathrm{~m}$ in every location (Fig. $4 \mathrm{~b}$ and $4 \mathrm{~d}$ ).

Density and magnetic susceptibility data were used only as reference input for the petrophysical parameters of the units. The main discrepancies may be due to the fact that the number of samples is very limited and the metamorphic grade varies within the area in parallel with the physical properties of the rocks (Best, 2003). Furthermore, it has been shown that for any lithological group, there is a possible range of values of two to four orders of magnitude in the magnetic susceptibility (Clark, 1997). Additionally, the weathering of rocks diminishes the values of magnetic susceptibility due to the metastable nature of both magnetite and pyrrhotite at the surface of the Earth (Isles and Rankin, 2013). 

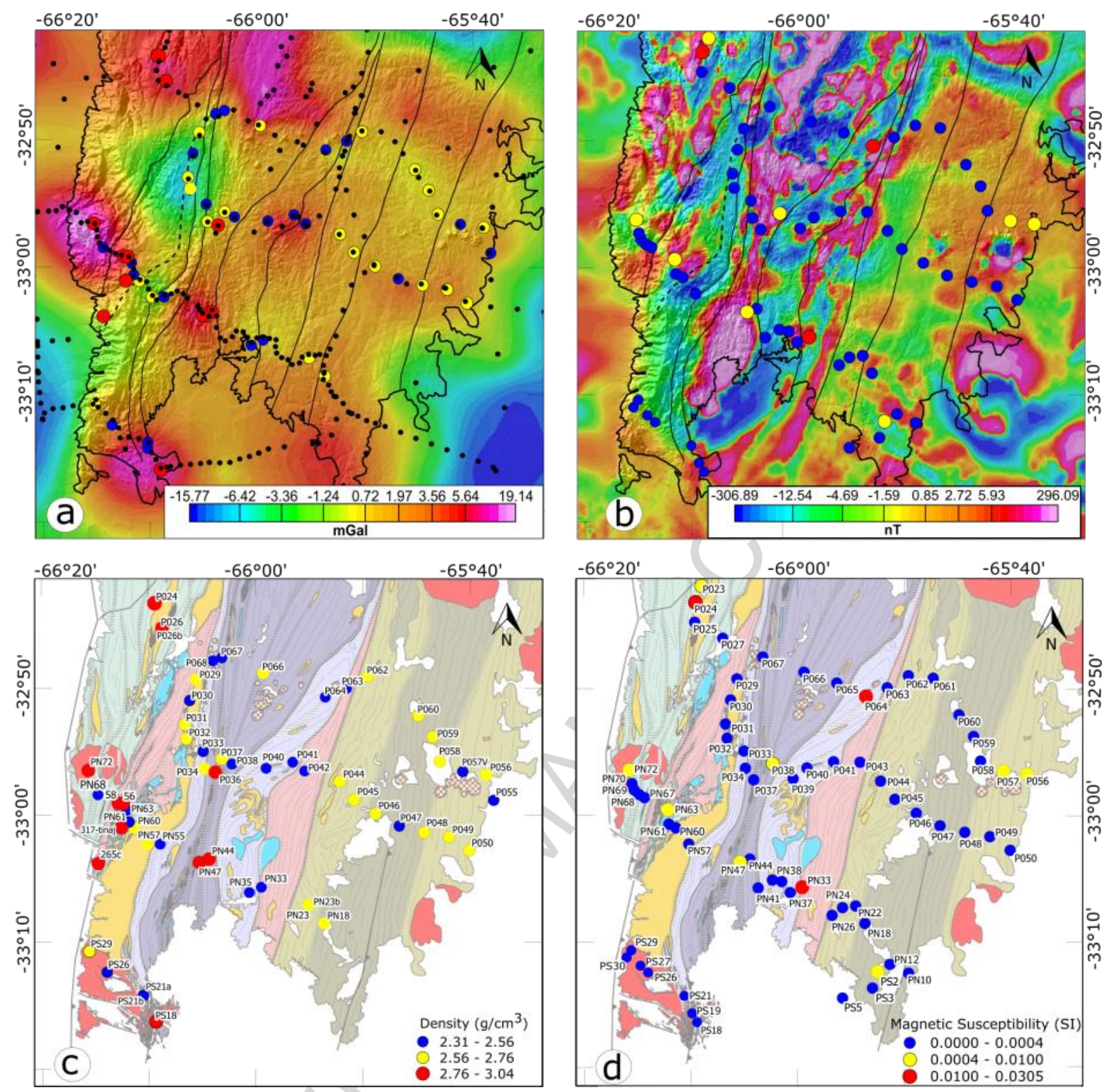

Fig. 4: Geophysical datasets used in the inversion process. In (a) and (b) black dots represent gravity stations and black lines the limits of the main geological units. Dashed lines delineate the western limit of the La Escalerilla Pluton. a) Residual Bouguer Anomaly map with density samples superimposed (colour circles, scale in Fig. 4c), b) Residual TMA map with magnetic susceptibility samples superimposed (colour circles, scale in Fig. 4d), c) Density samples locations, d) Magnetic susceptibility measurements locations.

\subsection{D litho-constrained joint inversion of gravity and magnetic data}

The geophysical inversion method carried out in this paper was implemented using GeoModeller software developed by Intrepid Geophysics and BRGM (Calcagno et al., 2008;

Guillen et al., 2008). This method was designed for cases in which the geology is known in scattered places of the surface. Based on the theory of potential fields, this technique interpolates and extrapolates information taking into account the geological contacts, their orientation and the order of the formations in the stratigraphic column. The objective is to create a 3D model to describe the geometry and petrophysical parameters of the geological 
units (McInerney et al., 2005). Then the model is discretized into voxels (rectangular prisms with properties given by the geological unit they represent) in order to make the computational calculations. Through forward modelling, the geological units of the model are adjusted and their geophysical responses are approximated to the original geophysical grids. Then its physical properties (density and magnetic susceptibility) are optimized using least squares analysis and the model is again adjusted. Finally, the litho-constrained stochastic inversion is carried out.

This non-deterministic method of inversion modifies, with each iteration and within a range determined by the user, one cell of the voxel model, either in terms of geologygeometry or rock property. The revised geophysical response is recomputed following the small change, and assessed against observed gravity and magnetic data. If the misfit is better than the last iteration, the model is kept. If the misfit is worse, the model is generally rejected. Given the nature of the inversion process (not deterministic) iteration do not cease when a specified low limit is reached. The process continues a number of times given by the user and models which converge up to an overlap zone of 3 different datasets (geology, magnetics and gravity) are kept (Fig. 5) and finally given through likelihood statistics (Gibson et al., 2013). As a final result we obtain the most probable geological model, and its distribution of densities and magnetic susceptibilities. The complete inversion process carried out for this publication can be seen in Appendix A.

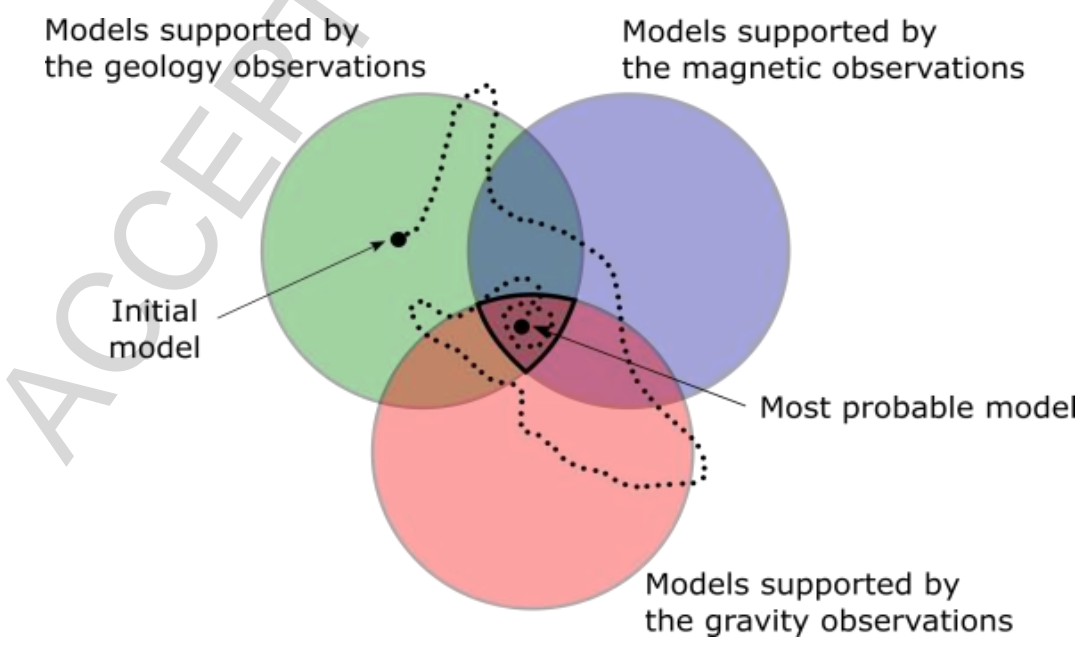

Fig. 5: Litho-constrained inversion process sketch. This method explores possible models varying the geology, density and magnetic susceptibility within a range determined by the user. The models that converge to the central area (3 independent datasets) are stored and delivered in the form of likelihood statistics (Modified from Gibson et al., 2013). 


\section{Results}

Results show a high correlation between the gravimetric anomalies and the density samples (Fig. 4a). In its majority, the samples with high densities are located in the high gravimetric zones, especially in the area of El Volcán, the southern sector of the Nogolí Metamorphic Complex and the northern sector of the Pringles Metamorphic Complex. For the magnetic anomalies, the correlation was not so satisfactory with respect to the samples but a high correlation can be observed with respect to the geology. It should be considered that the data spacing in this case is much smaller than in the gravimetric one. The magnetic maxima are mainly found in the Pringles Metamorphic Complex associated with the maficultramafic rocks and in the Ciénaga de Inti Huasi and Rio Guzman shear zones. High values of magnetic anomaly can also be observed in the Nogolí Metamorphic Complex and in the postorogenic plutons of Renca, La Totora and Las Chacras-Potrerillo (Fig. 6).

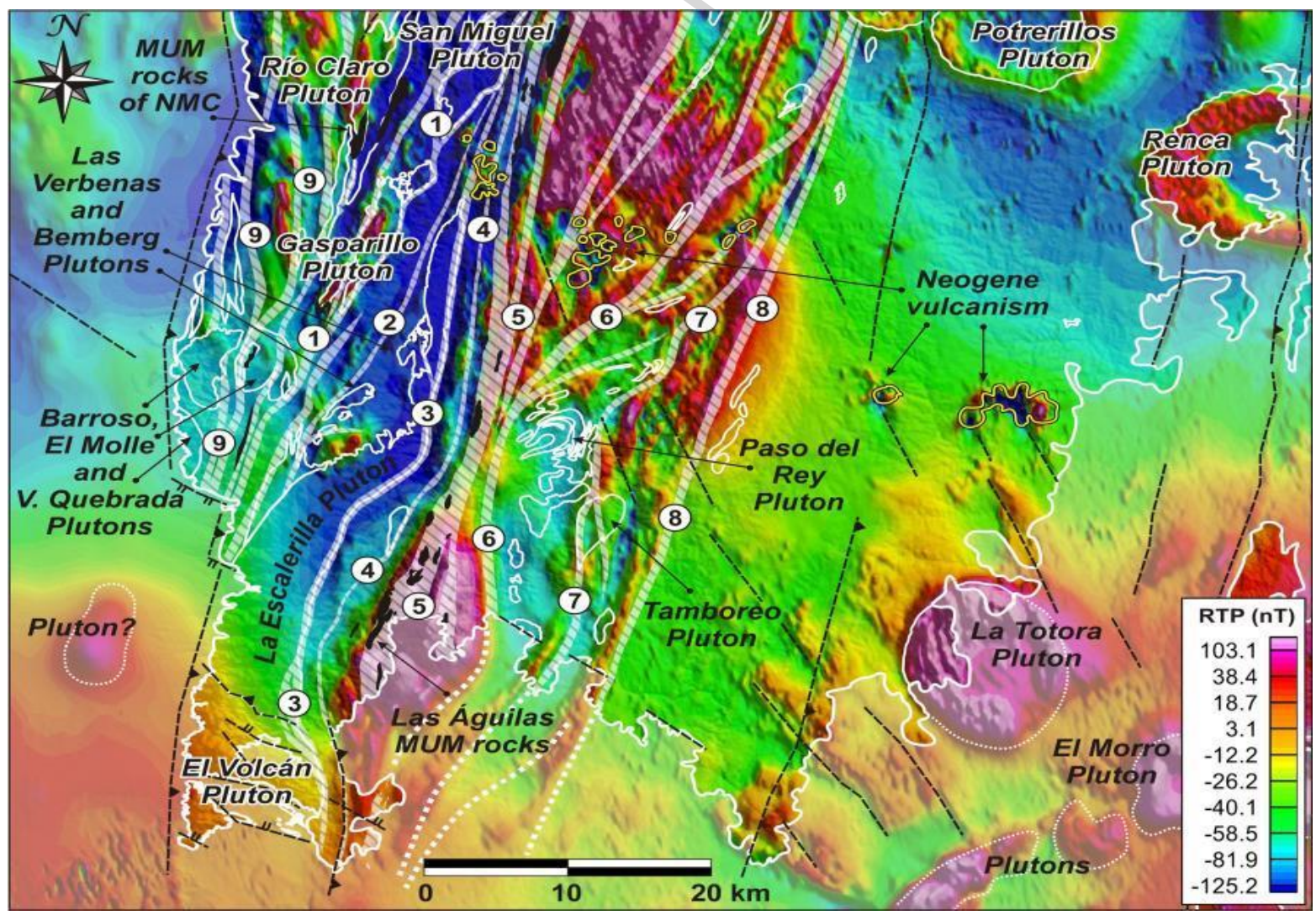

Fig. 6: RTP magnetic anomaly map of the study area with the geological interpretation. Solid white lines represent the contour of the SGSL and some important geological features (mostly plutons). Dashed black lines represent inferred and observed faults. Dashed thick white lines represent shear zones: 1) El Realito-Río de la Quebrada, 2) Pancanta-La Carolina, 3) La Escalerilla, 4) San Pedro-El Volcán, 5) La Arenilla, 6) La Troya, 7) Ciénaga de Inti Huasi, 8) Río Guzmán, 9) Río Los Bayos - Funes, and others of the Nogolí Metamorphic Complex (undifferentiated). 
The final 3D model with 10 control sections (in which the inferred geology calculated by the models can be observed up to a depth of $6 \mathrm{~km}$ ), and the density and magnetic susceptibility cubes are presented in Figure 7. A remarkable feature is the variation of the magnetic susceptibility on the surface that coincides with the "axis" of the doubly-vergent transpressive mega-structure where the ultramafic rocks outcrop. In Appendix A, the evolution of the petrophysical values along with the initial and final models are described in more detail.

Gravity inversion resulted in a general misfit (RMS misfit in the whole grid) of 0.3 mGal (Fig. 8 a, b, c, d). Differences between the observed and the computed grid, especially in the Pringles Metamorphic Complex, could be related to mafic-ultramafic rocks that were not considered in the model. Other differences can also be associated to density variations in the postorogenic granitoids mostly in the El Molle/Barroso and El Volcán areas. Regarding the magnetic anomalies, the adjustment was good in most of the grid obtaining a general misfit of 19.2nT (Fig. 8 e, f, g, h). However, isolated misfit areas in the magnetic grid could correspond to unmapped mafic-ultramafic rocks, such as in the Nogolí Metamorphic Complex. These may also be caused by bodies of small size that were not taken into account due to the regional character of the model. After 20 million iterations, the misfit for both datasets became nearly horizontal (Fig. $8 \mathrm{~d}, \mathrm{~h}$ ). Consequently, it is assumed that a greater number of iterations would not produce significant changes in the results. 
(a)
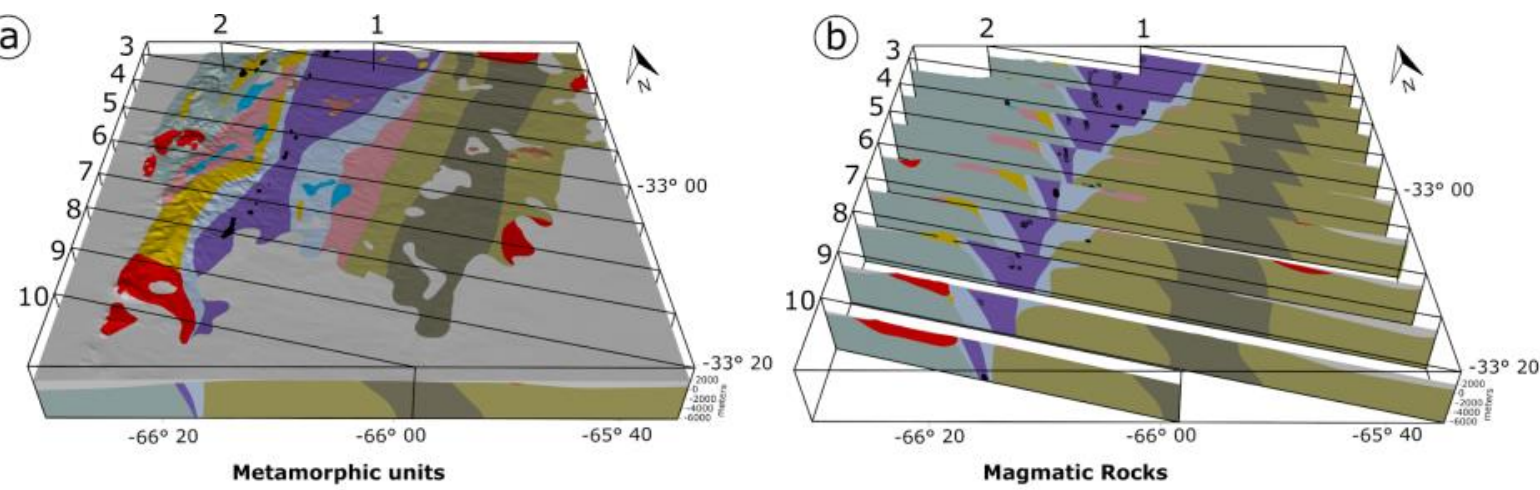

$\square$ San Luis Formation
$\begin{aligned} & \text { Pringles Metamorphic Complex } \\ & \text { San Jose Complex - Micaschist Group }\end{aligned}$
Conlara Metamorphic Complex
Migmatites - Schists

Neogene Volcanic rocks

Famatinian orogenic I-type quartz-diorites, tonalites and Famatinian late to post-orogenic granodiorites

granitoids

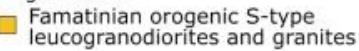
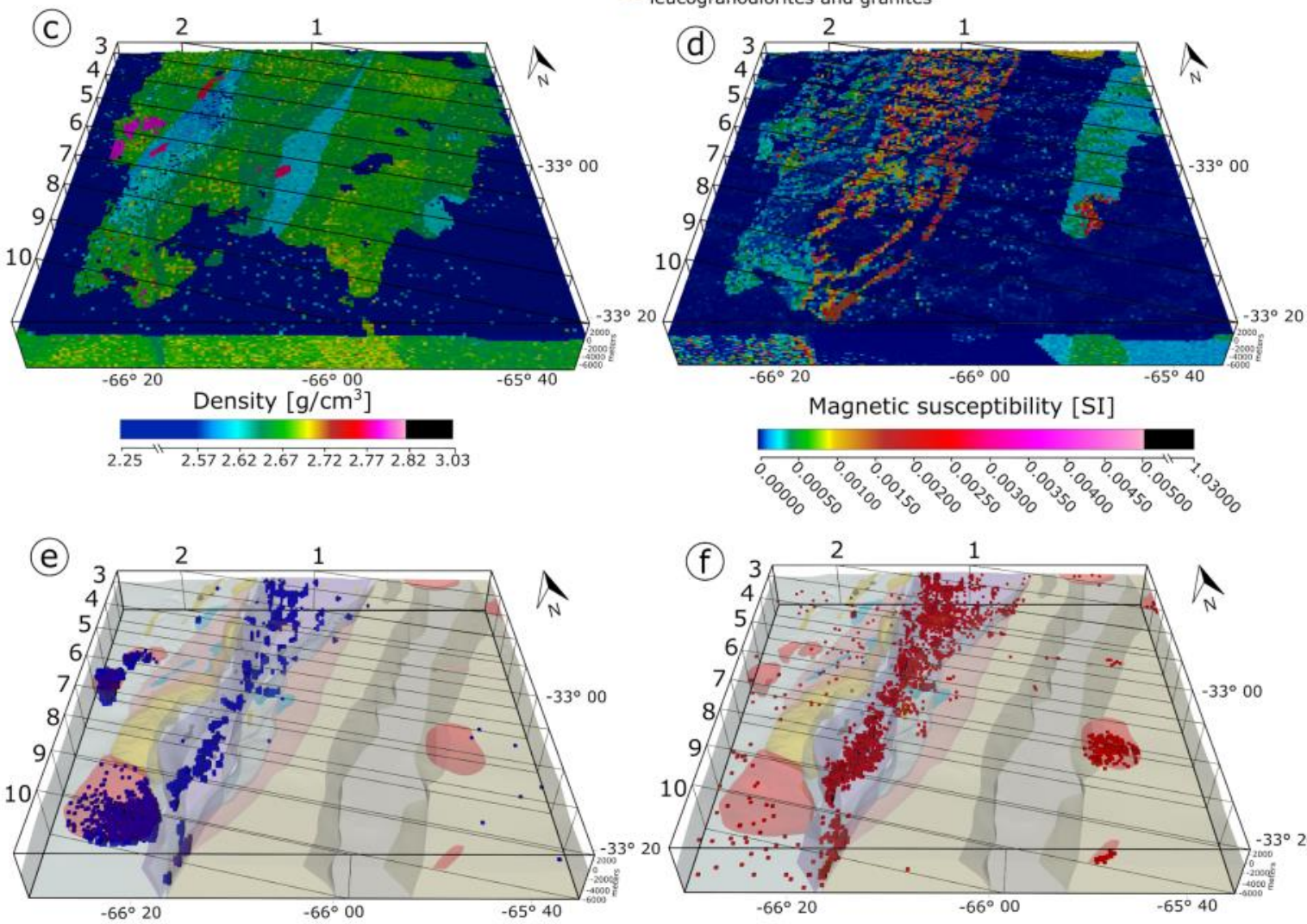

- High density values $\left[>2.80 \mathrm{~g} / \mathrm{cm}^{3}\right]$

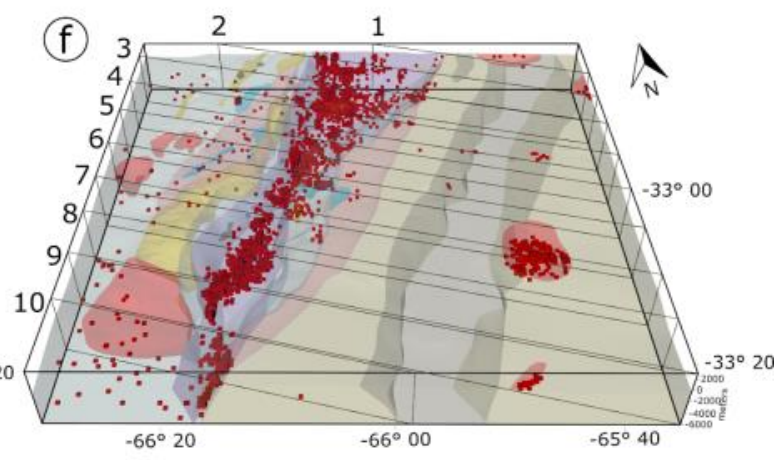

High magnetic susceptibility values [> $0.025 \mathrm{SI}]$

Fig. 7: a) 3D view of the geological units with 10 control sections perpendicular to the main structures. b) Distribution of the geological units in the control sections. c) Final density cube. d) Final magnetic susceptibility cube e) High density values f) High magnetic susceptibility values 


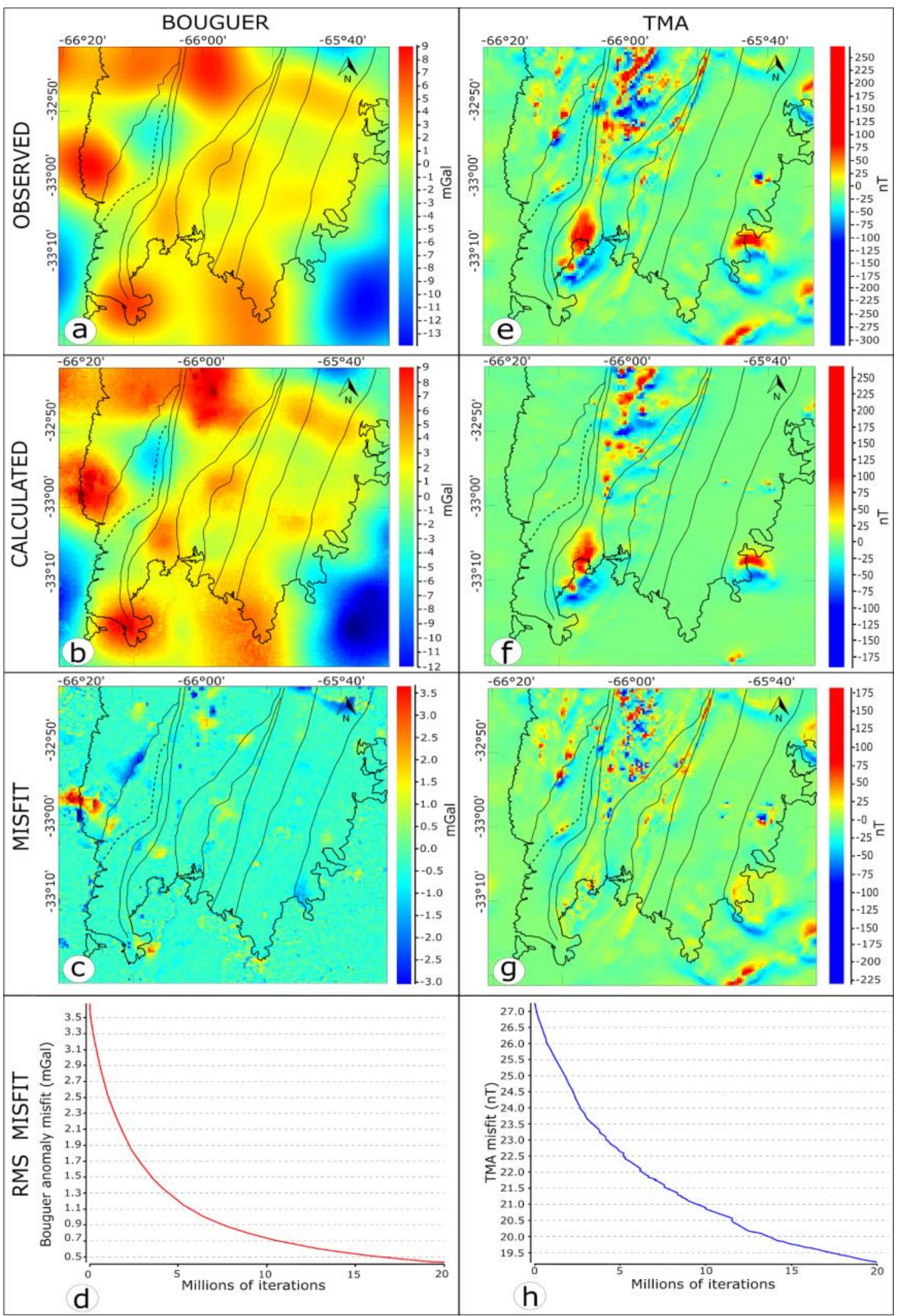

Fig. 8: Final results of the gravity (left) and residual magnetic (right) data inversion. a) Residual Bouguer anomaly. b) Bouguer anomaly produced by the 3D model. c) Misfit between the observed and the modelcomputed Bouguer Anomaly. d) RMS misfit of the whole gravity grid. e) Residual TMA. f) TMA produced by the 3D model. g) Misfit between the residual TMA and the model-computed TMA. h) RMS misfit of the whole magnetic grid. 


\subsection{D shape of the San Luis Shear System}

A simplified sketch of the San Luis Shear System is presented in Fig. 9. This model is based on the projected surface structural data and the results of the inversion model (Figs. A8 to A12 in Appendix A). Results suggest that most of the analysed shear zones continue towards the depth with the same inclination as the angles measured on the surface. However, some of them $(1,7$ and 8$)$ become horizontal and then vertical in the central area. In the La Arenilla shear zone (5) foliations are vertical to sub-vertical, between $86^{\circ} \mathrm{NW}$ and $70^{\circ} \mathrm{SE}$, with down-dip stretching lineations. Taking into account the whole set of shear zones it resembles a "positive flower structure". Therefore, most of the shear zones could intercept at depth to form a single belt of ductile deformation, which can be similar to a suture zone or vertical extrusion channel (at a depth $>6 \mathrm{~km}$ ). 


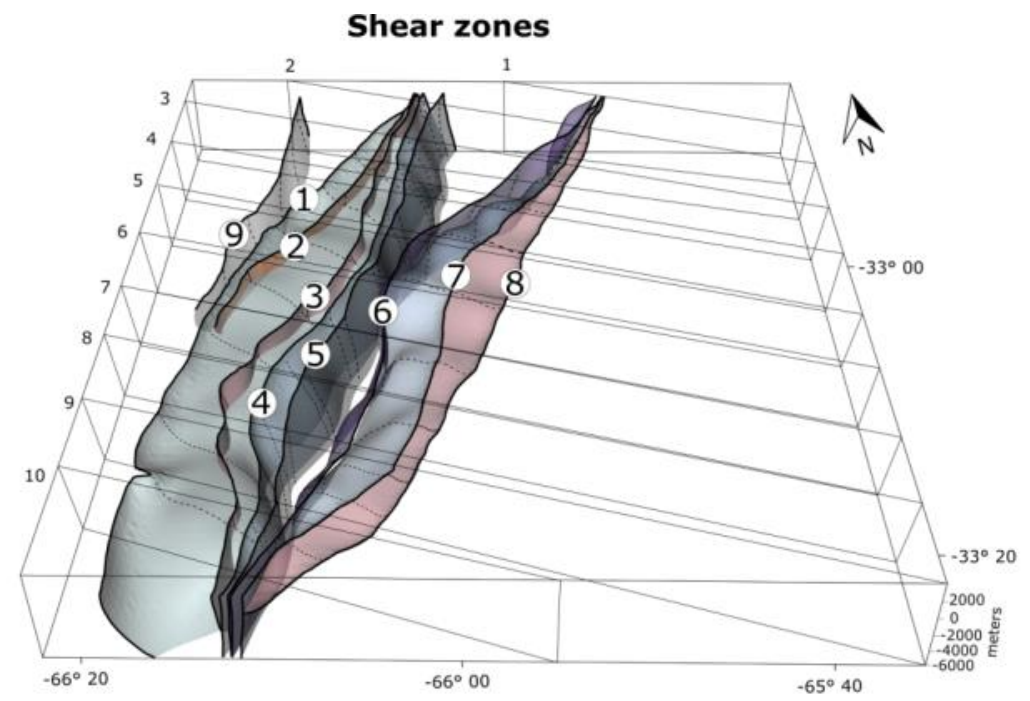

SECTION 4

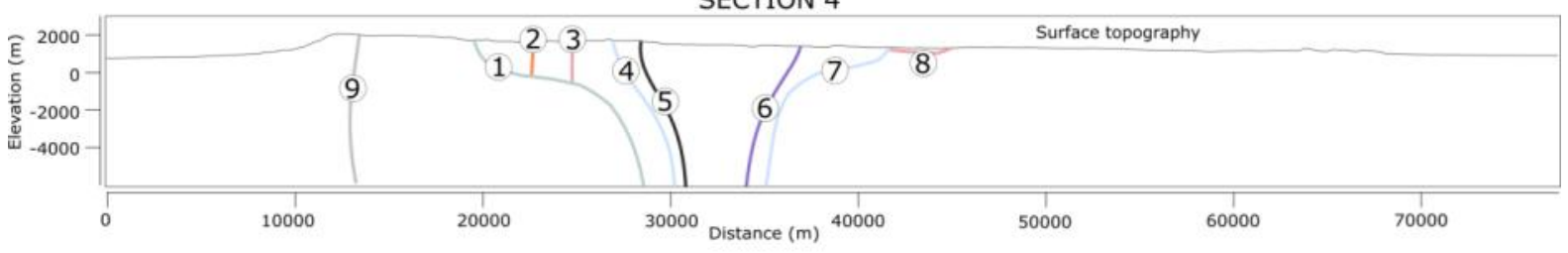

SECTION 6

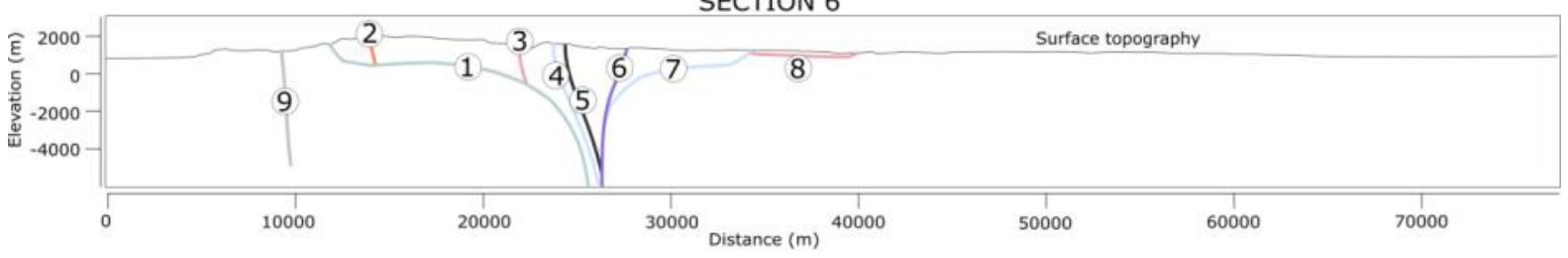

SECTION 8

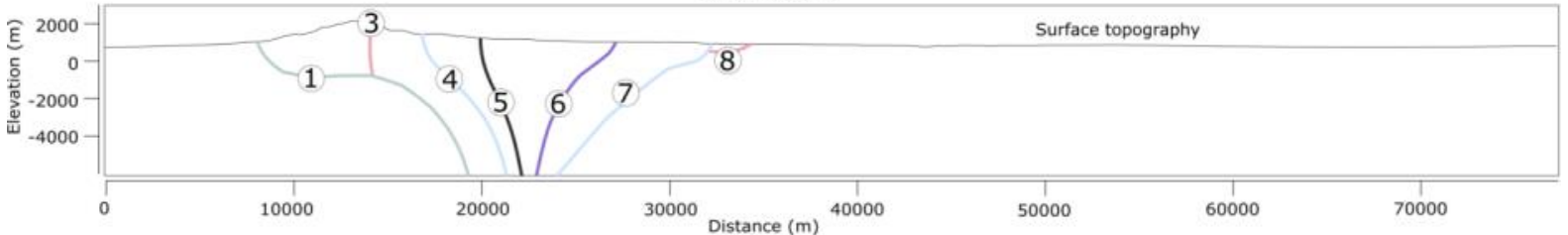

SECTION 10

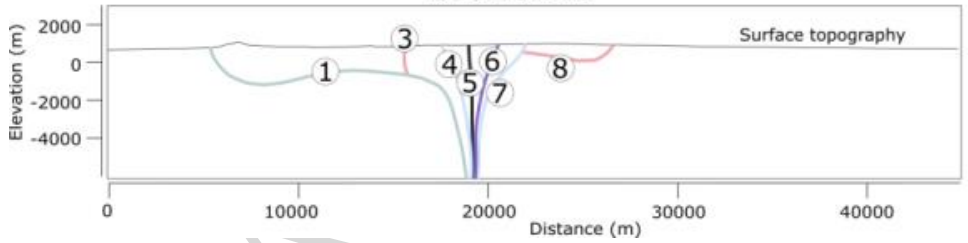

Fig. 9: 3D view of the San Luis Shear System with sections 4, 6, 8 and 10 showing the shape of the shear zones at depth. 1) El Realito - Río de la Quebrada. 2) Pancanta - La Carolina. 3) La Escalerilla. 4) San Pedro - El Volcán. 5) La Arenilla. 6) La Troya. 7) Ciénaga de Inti Huasi. 8) Río Guzmán. 9) Río Los Bayos - Funes.

\subsection{D shape of the Nogoli Metamorphic Complex}

The eastern boundary of the Nogolí Metamorphic Complex (Fig. 10a) is located below the western belt of the San Luis Formation and the La Escalerilla granitic pluton. 
According to the model, the contact with the Micaschist Group (Pringles Metamorphic Complex) occurs with high angles (around $70^{\circ}$ ), and occasionally in a sector with the Conlara Metamorphic Complex, where the Pringles Metamorphic Complex thins out. Within this complex, mafic-ultramafic, tonalitic and granitic rocks are present on the surface and the model suggests that they must also be present at depth (Fig. 10f and 10g). Several bodies located preferentially in the northern sector of the complex, where they can be observed on the surface (e.g. Pampa de las Invernadas), would represent the mafic-ultramafic rocks. The northern, southern and western limits of the Nogolí Metamorphic Complex are outside the modelled area and their 3D shapes are still unknown.

\subsection{D shape of the Conlara Metamorphic Complex}

Two distinct zones were recognized within the Conlara Metamorphic Complex based on geological mapping. One is related to a high degree of metamorphism and is

predominantly composed of migmatites that are located in a central strip. The other zone is located on both sides of the previous one and is related to a lower degree of metamorphism. It consists mainly of schists with a characteristic compositional banding. In the 3D model (Fig. 10b) the migmatite zone (central) is represented by a tabular morphology with a slight inclination towards the east. Conversely, the San Luis Formation and the Micaschist Group represent the western limit of the schist zone, located in the western sector of the Conlara Metamorphic Complex. This border presents a slight inclination towards the west, which culminates vertically in the deep central sector of the San José Complex. Eventually a deep contact with the Nogolí Metamorphic Complex can be observed. The eastern limit of the Conlara Metamorphic Complex exceeds the limits of the model and its 3D shape is not completely known. However, there is consensus that it would be represented by the Guacha Corral mega-shear zone (Sims et al., 1998; Whitmeyer and Simpson, 2004; Semenov and Weinberg, 2017; among others).

\subsection{D shape of the PMC}

The San José Complex (Fig. 10c) has a funnel-shaped cross-section that thins downwards with different thicknesses depending on the latitude (pinch and swell megastructure or mega-boudinage). Modelling suggests that the mafic-ultramafic rocks hosted in 
the first $6 \mathrm{~km}$ of the San José Complex correspond to a $25 \%$ of its volume, and are scattered at different depths. The greater or lesser concentration in volume of these rocks is, according to the obtained model, directly related to the thickness of the San José Complex (Fig. 10g). The Micaschist Group forms two packages, one on either side of the San José complex, with opposite dips (Fig. 10d). The surfaces that limit it are curved and contoured. The boundaries between both Micaschist Group belts and both San Luis Formation belts present intrusions of granites and pegmatites; the largest being the La Escalerilla Pluton. This granite is located between the western strips of the Micaschist Group and the San Luis Formation, although these borders converge at depth below the pluton and towards the north.

\subsection{D shape of the San Luis Formation}

The best fit for this unit is achieved when a reduced thickness $(<2 \mathrm{~km})$ and a horizontal base are considered (Fig. 10e). The border with the Conlara Metamorphic Complex and the border with the Nogolí Metamorphic Complex are characterized by straight traces; nevertheless, the internal borders (limit with the Micaschist Group and the La Escalerilla Pluton) are curved. Both strips of this formation culminate to the north in a thin wedge-shape. Regarding the magnetic inversion, high values of magnetic susceptibility were found especially in the contact with the Conlara Metamorphic Complex (Río Guzmán Shear Zone).

\subsection{D shapes of the plutonic plutons}

Although the model did not focus on the shape of the plutons, a particular feature of the model is that most of the Ordovician tonalitic and granitic bodies in the SGSL are longer in the N-S direction and are horizontally flattened, especially those that are currently exposed on the surface (Fig. 10f). To get a more precise shape of these bodies, it would be necessary to acquire more data in the areas of interest and model them individually.

The most outstanding body of the orogenic magmatism in the area corresponds to La Escalerilla Pluton. According to the geophysical results, it has a flat base (in the central and southern parts) with a slight tilt to the east and a thickness close to $2 \mathrm{~km}$. Due to the conical shape of the pluton towards that limit (pipe-shape in profile), magma ascent can be interpreted through a feeder root located in contact with the Micaschist Group. This root 
disappears gradually to a depth of about $5 \mathrm{~km}$. Below this pluton, the Nogolí Metamorphic Complex is in contact with the Pringles Metamorphic Complex without the intervention of the San Luis Formation.

The vast majority of the postorogenic plutons are subcircular in plain view (Fig. 10f). In general, the subcircular shapes indicate that their feeder roots are situated in their central part. Furthermore, postorogenic bodies have thicknesses between 1 and $3 \mathrm{~km}$, which suggest that they have a flat morphology.

\subsection{D shape of Neogene plutons}

Because of their small volumes close to the surface, Neogene plutons (Fig. 10h) were difficult to properly model at the scale of the investigation carried out here. Mostly, these rocks have low density and a variable magnetic susceptibility. The 3D shape of the volcanic elements (domes, some lava flows and pyroclastic material) is observable on the surface because they protrude over the previously eroded relief of the basement. Their sizes are variable but do not reach large dimensions. 


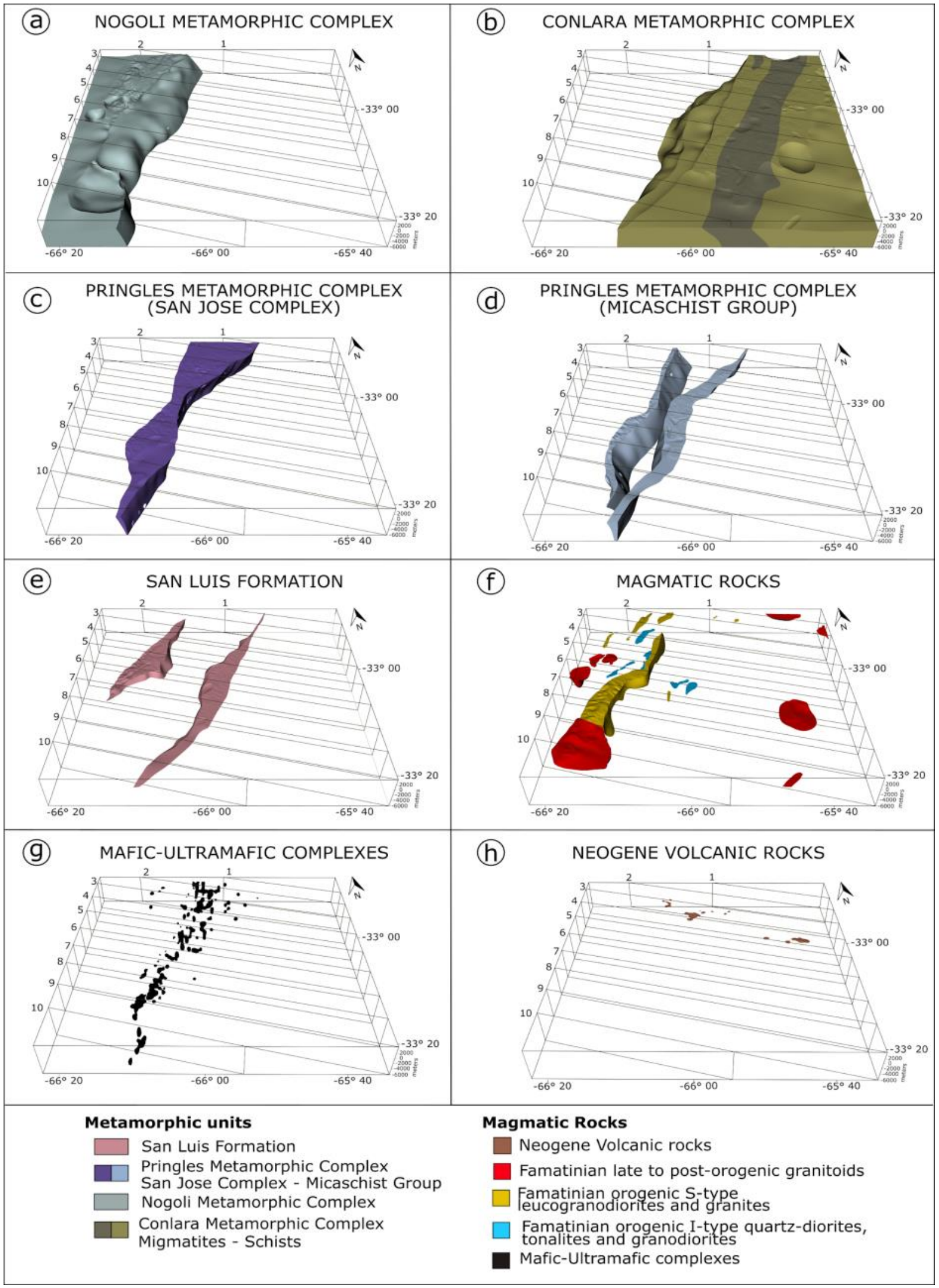

Fig. 10: 3D shape of the units present in the southern sector of the SGSL. a) Nogolí Metamorphic Complex. b) Conlara Metamorphic Complex. c) San José Complex (Pringles Metamorphic Complex). d) Micaschist Group (Pringles Metamorphic Complex). e) San Luis Formation. f) Famatinian orogenic and postorogenic plutons. g) Mafic-ultramafic rocks (most are in the Pringles Metamorphic Complex and some bodies in Nogolí Metamorphic Complex). h) Neogene volcanic rocks. 


\section{Discussion}

\subsection{Orogenic architecture and initial stage}

The morphology of the geological units together with the interaction of the structural elements and tectonic stresses resulted in a large-scale double-vergent structure covering the Pringles Metamorphic Complex and the San Luis Formation. In this context, the San José Complex (granulite facies of the PMC) is the extruded core above the Micaschist Group (amphibolite facies of the PMC), and this, in turn, rides on the San Luis Formation (greenschist facies), while the Nogolí Metamorphic Complex and the Conlara Metamorphic Complex form the external substrate of the doubly-vergent transpressive belt. This is supported by the thermo-barometric data of the different units (Hauzenberger et al. 2001; Ortiz Suarez and Casquet, 2005; Morosini and Ortiz Suárez, 2011, 2013; Cruciani et al., 2012; Morosini et al., 2014; Delpino et al., 2007, 2016; Verdecchia et al., 2018) which suggest an inverted disposition of the metamorphism by tectonics processes (Fig. 11a, Ortiz Suarez and Casquet, 2005, Morosini et al., 2014). Moreover, this interpretation is justified by the surface structural data, primarily the kinematic features of the San Luis Shear System (Figs. 2, 3 and Table 1), which indicates a sinistral transpression (von Gosen 1998a; Delpino et al., 2001; Morosini et al., 2014).

There are notable differences between the interpretations that can be formulated if only surface structural data are taken into account, and those in which the outcome of the litho-constrained stochastic inversion model are considered. For example, although the Río Guzmán shear zone dips with high angles to the east (at the current exposure level), the 3D model does not show high dipping angles at greater depths. This necessarily implies a strong sub-horizontal structural decoupling (decollement or take-off surface) between the San Luis Formation and the Conlara Metamorphic Complex. A delayed (Devonian) tectonic activity could have truncated this decollement, thus generating a shear zone in blocks between these units, with high angle and western vergence (where San Luis Formation is the footwall). These interpretations indicate two periods of shearing between the San Luis Formation and the Conlara Metamorphic Complex (Fig 11b). 

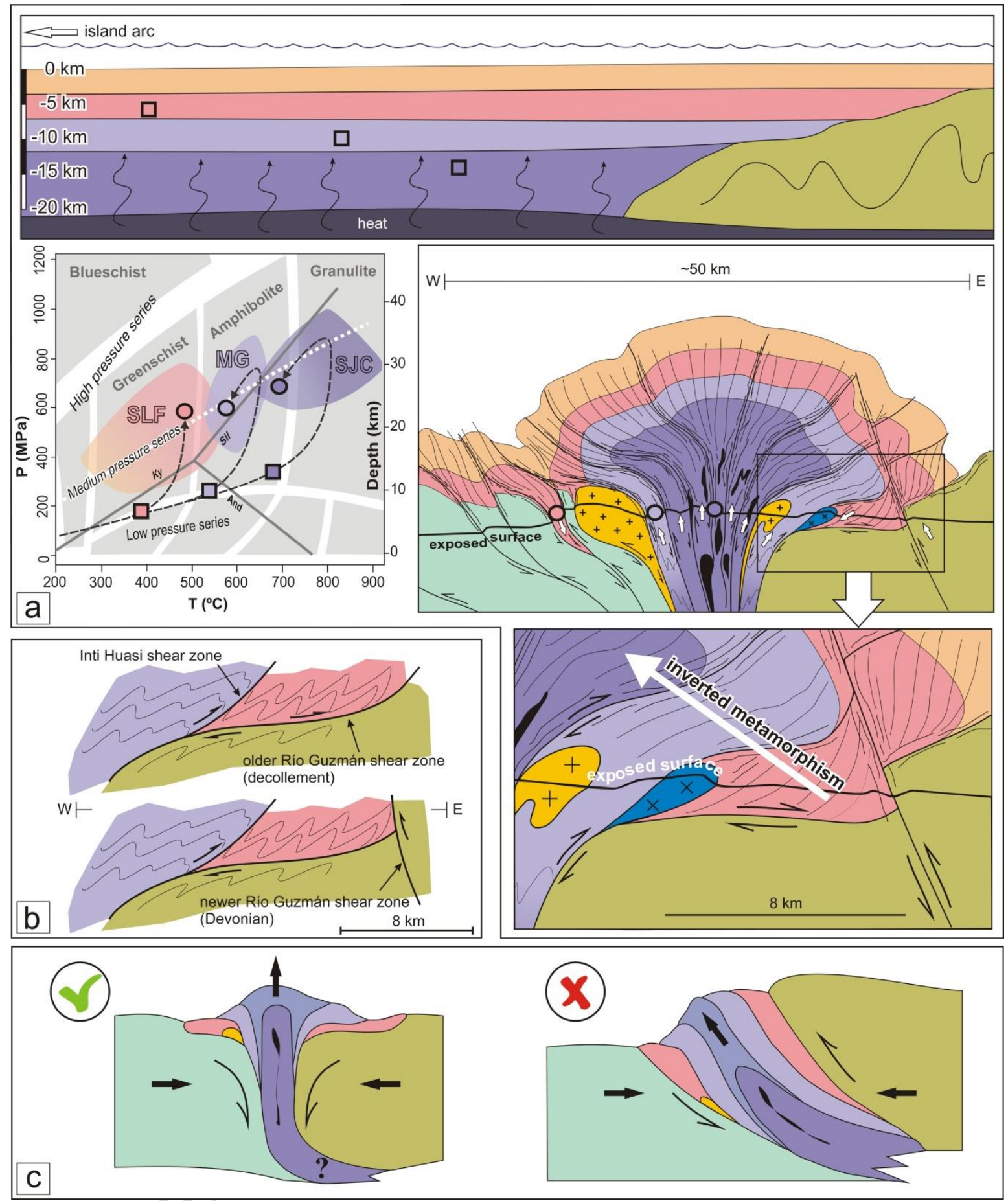

Fig. 11: a) P-T-t paths interpretation for the San Luis Formation (SLF), the Micaschist Group (MG) and the San José Complex (SJC). The colour boxes represent the initial stage of metamorphism (prograde trajectory), associated with a thermal input generated in an ensialic back-arc setting (picture above). The colour circles represent the P-T metamorphic conditions of the particles during the development of the doubly-vergent structure (image on the right). By the time the San Luis Formation reached its metamorphic climax (burying process), the Pringles Metamorphic Complex was on its retrograde (counterclockwise) path due to exhumation. The fields represented in the P-T diagram have been delimited according to the datasets of Hauzenberger et al. (2001); Ortiz Suarez and Casquet (2005); Morosini and Ortiz Suárez (2011, 2013); Cruciani et al. (2012); Morosini et al. (2014); Delpino et al. (2007, 2016); and Verdecchia et al. (2018), considering the error ellipses. b) Scheme of the detachment surfaces and deformation stages on the eastern boundary of the large-scale "doubly-vergent" structure. c) Schematic profiles of the mega-shear zones. Left (proposed as correct): model based on a pure shear strain regime (considering all individual shear zones as parts of a single system). Right (proposed as incorrect): model based on a simple shear strain regime. 
The low dip angle of the Ciénagas de Inti Huasi and the older Río Guzmán shear zones, suggest that they acted as detachments that placed the eastern Micaschist Group plus the San Luis Formation over the Conlara Metamorphic Complex. In this case, movement on the hanging wall of the detachment had vergence to the east. In addition, the deeper Inti Huasi shear zone truncated the shallower Río Guzmán shear zone forming an imbricate sheet (see the western limit of the Conlara Metamorphic Complex in Fig. 10b and Fig 11b) and becoming vertical in the central zone and parallel to the La Troya, La Arenilla and San Pedro-El Volcán shear zones (Fig. 9). Likewise, but with opposite vergence, the El RealitoRío de la Quebrada shear zone acted as a decollement for the western strip of the San Luis Formation over the Nogolí Metamorphic Complex. This take-off surface acted as a ramp for the emplacement of the La Escalerilla Pluton (see eastern limit of the Nogolí Metamorphic Complex in Fig. 9a).

Our results indicate that the transpressive belt does not correspond to a mega-shear zone accommodating simple shear. The shear system is neither tabular nor parallel, and movement has opposite senses in the west and in the east (Fig. 2 and 11c). In the west, almost all shear zones have western vergence with reverse movement and small sinistral strike-slip component (von Gosen 1998a; Morosini et al., 2014). In the east, nearly all shear zones have reverse movement with a small sinistral strike-slip component, but unlike the western shear zones, the eastern ones have eastern vergence (Ortiz Suárez and Casquet, 2005).

Results suggest an extrusion by vertical flow of the hot rocky material, where the hanging wall (or extrusion core) coincides with the San José Complex (migmatites of the Pringles Metamorphic Complex) and the footwalls are both flanks of San Luis Formation. This structure was produced from intermediate levels of the crust. In order to justify the enormous lithospheric shortening during the collision, below intermediate crustal levels (greater than the current $6 \mathrm{~km}$ depth), this structure should be rooted in a horizontal megathrust (of lystric shape?) that involves the whole crust.

The reduced to the pole (RTP) anomaly map (Figs. 6 and 12a) shows that the great majority of the shear zones outcropping within the Pringles Metamorphic Complex and the San Luis Formation (transpressive belt) present high magnetic values. This could have been caused by folding or shearing of rocks at moderate to high temperature (plastic deformation). This conditions allow the concentration of magnetite and pyrrhotite into low-strain zones, resulting in an increased magnetic susceptibility with respect to the surrounding rocks (Isles 
and Rankin, 2013). Furthermore, the thermal annealing of the grains after mechanical flow may increase grain-size and grain interconnectivity, further increasing the magnetic susceptibility. These interpretations are well documented in the Río Guzmán shear zone (Sims et al., 1998), whose positive aeromagnetic anomaly is particularly prominent.

A particular feature of the large-scale doubly-vergent structure is that the shape of the internal domain (San José Complex) is not perfectly parallel in a latitudinal sense; instead it shows variable width. This could be related to the restraining bends or restraining stepovers of the secondary strike-slip shear zones at depth, which may have developed pop-up structures in more superficial levels (currently eroded). In that sense, the presence of a larger volume of mafic-ultramafic rocks in the Las Águilas zone (Fig. 12b) is consistent with thicker inner cores domains of pop-up structures. The shape of the anomaly and the structural style of the sector closely resemble the laboratory experiments developed by McClay and Bonora (2001). This analogy indicates that there could be an underlapping of shear zones with a restraining stepover of $30^{\circ}$ (Fig. 12c). Moreover, this would have generated a window towards the lower crust levels and a connection to the mantle allowing the entry of maficultramafic material into the core of the pop-up structure.

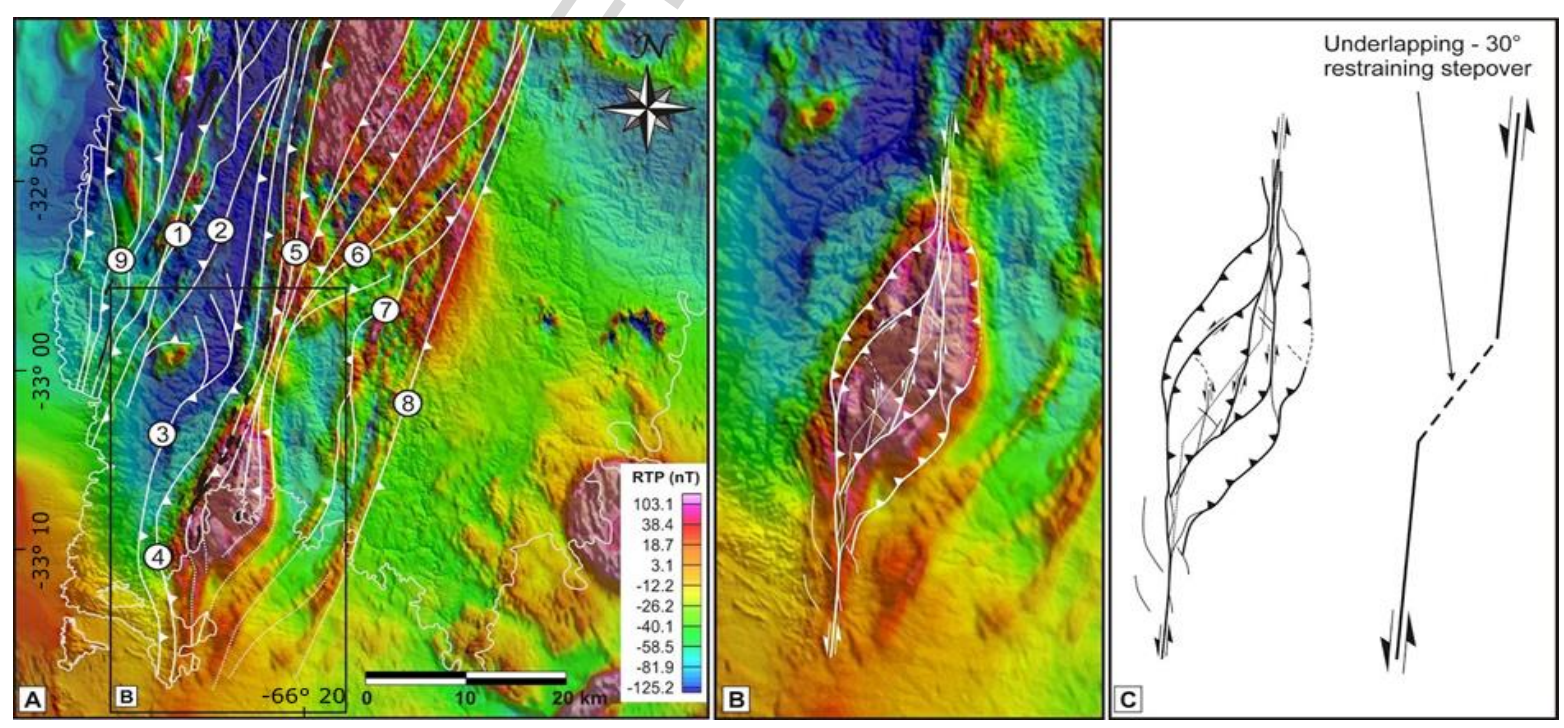

Fig. 12: a) RTP anomaly map with superposition of the San Luis Shear System. The numbers correspond to the main shear zones shown in Figures 2 and 9. 1) El Realito-Río de la Quebrada, 2) Pancanta-La Carolina, 3) La Escalerilla, 4) San Pedro-El Volcán, 5) La Arenilla, 6) La Troya, 7) Ciénaga de Inti Huasi, 8) Río Guzmán, 9) Río Los Bayos - Funes, and others of the Nogolí Metamorphic Complex (undifferentiated). b) Zoom of the RTP map in the Las Águilas sector. The strong positive magnetic anomaly represents the San José Complex with its mafic-ultramafic intrusions. c) Figure modified from McClay and Bonora (2001). 
A previously structured substrate formed by the Nogolí and Conlara Metamorphic Complexes, and a transpressive belt formed by the Pringles Metamorphic Complex and the San Luis Formation (extruded during the Famatinian collision) is inferred. When the Famatinian back-arc was closed by tectonic inversion, the Nogolí and Conlara Metamorphic Complexes compressed the Pringles Metamorphic Complex and the San Luis Formation sequence. Then, when the system could no longer be compressed horizontally, the vertical extrusion of the Pringles Metamorphic Complex occurred, thus forming the transpressive San Luis Shear System (Fig. 13).

Our interpretations indicate that the San Luis Formation does not correspond to a sedimentary sequence deposited in a foreland basin as interpreted by Chernicoff and Ramos (2003). On the contrary, the San Luis Formation was the upper part of a thick marginal basin that also contained the sedimentary protoliths of the Nogolí and Pringles Metamorphic Complexes, i.e. part of an extensive accretionary margin (e.g. Ducea et al., 2010; Cristofolini et al., 2012). In that sense, the results of this study are difficult to reconcile with a model of continent-to-continent collision for the Pampean orogeny (between 530 and $515 \mathrm{Ma}$ ). Rather they support a ridge subduction, or ridge-trench collision (Schwartz et al., 2008).

According to the maximum sedimentation ages for the Nogolí and Pringles Metamorphic Complexes, and the San Luis Formation sedimentary protoliths (Sims et al., 1998; Steenken et al., 2006; Drobe et al., 2009), the development of a marginal deep-water marine basin for the Cambrian (530 Ma) is interpreted (Fig. 13a). During the Famatinian orogeny, part of these sediments formed the substrate in which the island volcanic arc was developed (Nogolí Metamorphic Complex). Meanwhile, an ensialic back-arc environment was developed on the sedimentary protoliths of the Pringles Metamorphic Complex and the San Luis Formation (Fig. 13b). Finally, all of them were exhumed as metamorphic rocks during the closure of the back-arc basin and the collision of the Cuyania/Precordillera microcontinent (Fig. 13c).

There are at least three reasons to support that the San Luis Shear System acted diachronically during the development of the transpressional belt: 1) there are different metamorphic degrees, regardless that they usually show evidence of reactivations, where a low-penetrative and low-temperature deformation is superimposed on a high-penetrative and high-temperature deformation (cooling exhumation), 2) the relative and absolute ages of some 
of the shear zones show different temporal ranges (Table 1), and 3) the geophysical model suggests truncations between some of the shear zones at depth.
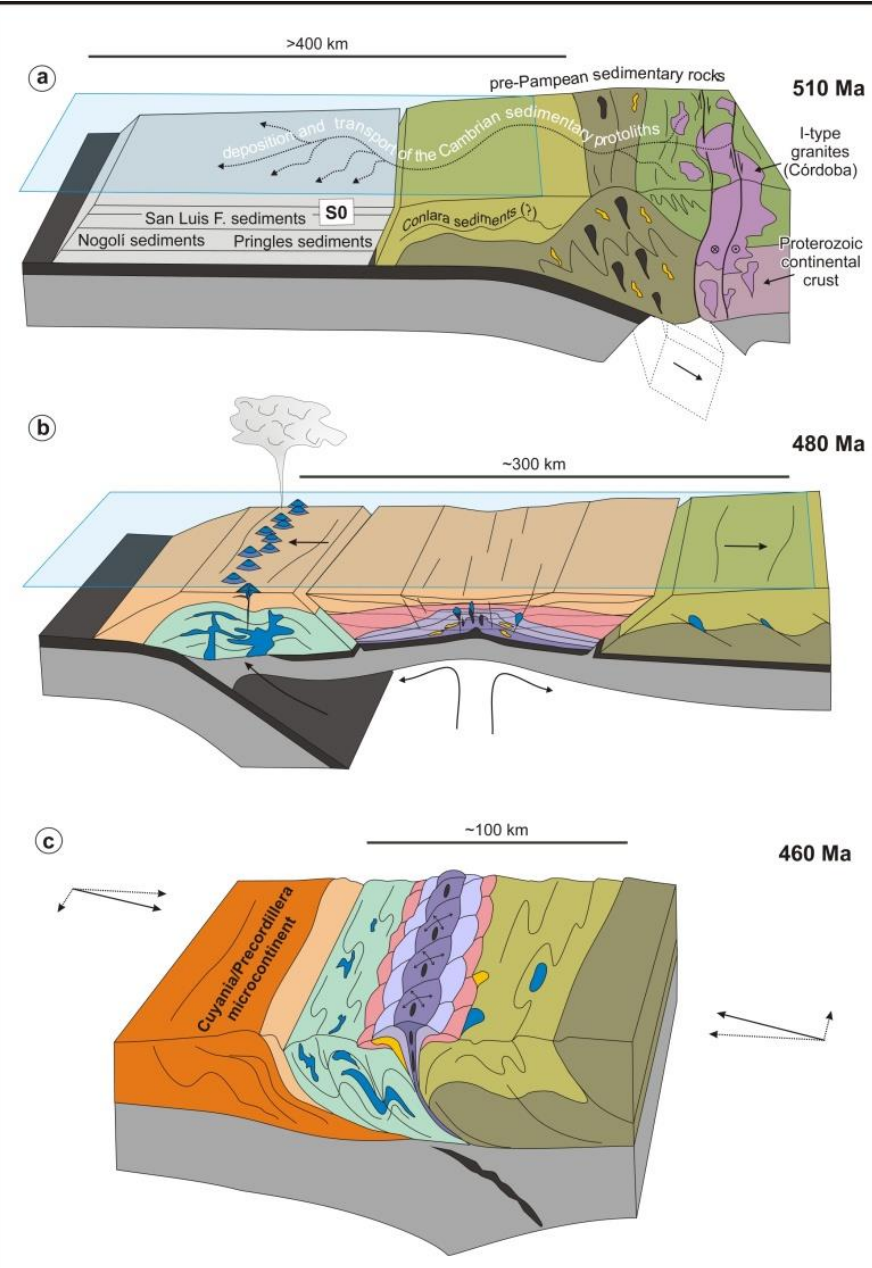

(d)

(f)
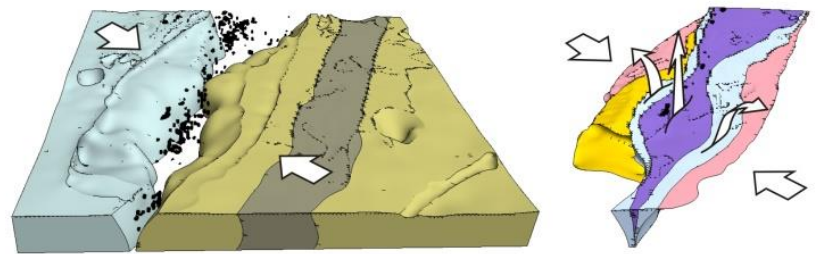

SLF $\square$ MG

\}PMC

NMC

Schists

Migmatites CMC

Fig. 13: Sketch of the tectonic evolution of the SGSL based on a ensialic back-arc environment for the origin of the La Jovita - Las Águilas mafic-ultramafic complex (Brogioni, 2001). a) Initial stage in $510 \mathrm{Ma}$, based on the non-collisional model for the Pampean orogeny (subduction to the east of a seismically active oceanic ridge) according to Schwartz et al., (2008). During and after the ridge-trench interaction the sedimentary protoliths sequence of the Nogolí and Pringles Metamorphic Complexes + San Luis Formation (Pampean synorogenic sediments of a marginal basin) are deposited. Towards the east of this basin the sedimentary rocks of the Conlara Metamorphic Complex are located. The protoliths correspond to the upper part of a pre-Pampean sedimentary 
sequence of passive margin, equivalent to the Puncoviscana Formation (northwest of Argentina). b) Development of the Famatinian back-arc (thermal input at $480 \mathrm{Ma}$ ). The arc axis (island arc) is located immediately to the west of the Nogolí Metamorphic Complex, developed as consequence of the new subduction in the front of the Pampean marginal basin. The Nogolí Metamorphic Complex is early structured (first Famatinian deformation D1) in comparison with Pringles Metamorphic Complex and San Luis Formation. The back-arc basin could be interpreted as a subduction rollback inducing asthenospheric upwelling. c) Extrusion of the Pringles Metamorphic Complex. Third Famatinian deformation D3 phase (San Luis Shear System). Construction of the large-scale doubly-vergent structure due to the collision of Cuyania/Precordillera terrane (from 465). Between (b) and (c) occurred the closing of the Famatinian back-arc, and development of the Famatinian deformation D2 phase (between 480 and $465 \mathrm{Ma}$ ). Extensive orogenic magmatism. d) 3D-shape of the crystalline pre-collisional substrate (footwall of the large-scale structure). The location of the maficultramafic rocks hosted in the Pringles Metamorphic Complex is also shown. f) 3D-shape of the doubly-vergent structure (hanging wall).

\subsection{Regional geotectonic interpretation during extrusion}

Taking into account the model results, two contrasting situations can be analysed regarding the mechanisms responsible for a transpressive extrusion in the SGSL. One possibility is to consider that the Cuyania/Precordillera terrane collided obliquely with the edge of Gondwana (Benedetto, 2004) favouring the development of a generalized transpression inward the continent. Another possibility is to assume that Cuyania/Precordillera acted as an indenter (micro-continent), with convex morphology, conditioning the style of deformation on the collided margin. In this model, the impact must have occurred with high convergence angle (e.g. Astini and Dávila, 2004; von Gosen and Prozzi, 2005). The best examples of the style of deformation are located along the entire Famatinian deformation belt (Fig. 14) from the north of the Sierra de Velasco to the Sierra Grande de San Luis. A compilation of ductile deformation zones is presented by Simpson et al. (2003), von Gosen and Prozzi (2005), Cristofolini et al. (2014), Larrovere et al. (2016) among others.

We consider that the last option explains better the development of a transpressive belt in the SGSL. There are notable differences between the general directions of the ductile shear zones (including double-vergent mega-structures) at different latitudes of the Famatinian Orogen. In the Valle Fértil, Velasco, Famatina, Ambato and Ancasti ranges, the main megastructures have NNW strike. In the Chepes, Ulapes and Sierra de Pocho (Córdoba) ranges, the structures have almost $\mathrm{N}$ strike (with small deviations). In the SGSL the predominant strike is NNE (Fig. 14b). These characteristics suggest different shortening directions; WSW-ENE in the northern sector, W-E in the central area, and WNW-ESE in the southern part (SGSL). A reasonable explanation implies a radial field of horizontal deviatoric stresses for the Famatinian orogenic belt caused by a subcircular morphology in the eastern boundary of the 
Cuyania/Precordillera terrane (Fig. 14b, c). A new arrangement in the directions of the horizontal deviatoric stresses occurred causing transpressional mega-structures in sites where the pre-collision metamorphic fabrics were oblique regarding the new shortening vectors.

In this model, each site of the collided edge acted with different kinematics. Although the orogeny was solved primarily by vertically reverse shear zones, lateral movement (strikeslip) associated with a partition of the deformation by large scale scape tectonics occurred in some sites of this orogen. Spagnuolo et al., (2011) investigated a counter-clockwise rotation for the Western Puna block (located immediately in the northern sector of the indentation). These authors interpreted that the rotation of this block occurred due to the tectonic escape related to the deformation generated by the collision of Cuyania/Precordillera.

Our interpretation suggests that there was a clockwise rotation of the horizontal deviatoric stress vectors in the area of the SGSL. This action resulted in a convergent noncoaxial general movement with a minor sinistral component during the progressive deformation of the shear zones. Consequence of this is the large-scale "doubly-vergent" structure observed in the model. Deformation in the transpressional belt in the SGSL started between the Lower Ordovician (given by the early intrusion of syn-orogenic plutons and the main regional metamorphism) with its peak in the Middle Ordovician ( 465 Ma). At that time a widespread cease in the arc magmatism in the Sierras Pampeanas occurred (e.g. Cristofolini et al., 2014) evidencing the indenting stage of the Cuyania/Precordillera terrane on the edge of Gondwana. This stage ended in Devonian times, when late to post-orogenic plutons intruded. This is supported by the cooling ages calculated in the area (Steenken et al., 2008). The model for the intrusion of the Las Chacras-Potrerillos batholith proposed by Siegesmund et al. (2004) would extend the sinistral kinematics of the shear zones up to $380 \mathrm{Ma}$. In this stage, an oblique shear NW and NE conjugated system (brittle-ductile deformation) allowed the channelling of the post-orogenic magmatism. This action may have been favoured by the accretion of the Chilenia terrane during the Achalian cycle (Sims et al., 1998) on the previously collided Cuyania/Precordillera terrane.

Finally, the most modern fracture system exposed the fossilized basement of the Sierra Grande de San Luis producing a slight tilt of the paleo-surface (calculated from a midline of the paleotopography on a digital elevation model) of $\sim 4^{\circ}$ towards the ESE (Costa el al., 2001b). We consider that this block inclination of the SGSL does not affect the model results, nor does it modify the interpretations made. In addition, it should be noted that the 
entire fracture system, that acted after the Cuyania/Precordillera and Chilenia collisions on the Gondwana margin, was conditioned by the Famatinian (high temperature deformation) ductile shear system as well as many of the discrete shear zones of Achalian age (brittleductile transition deformation).
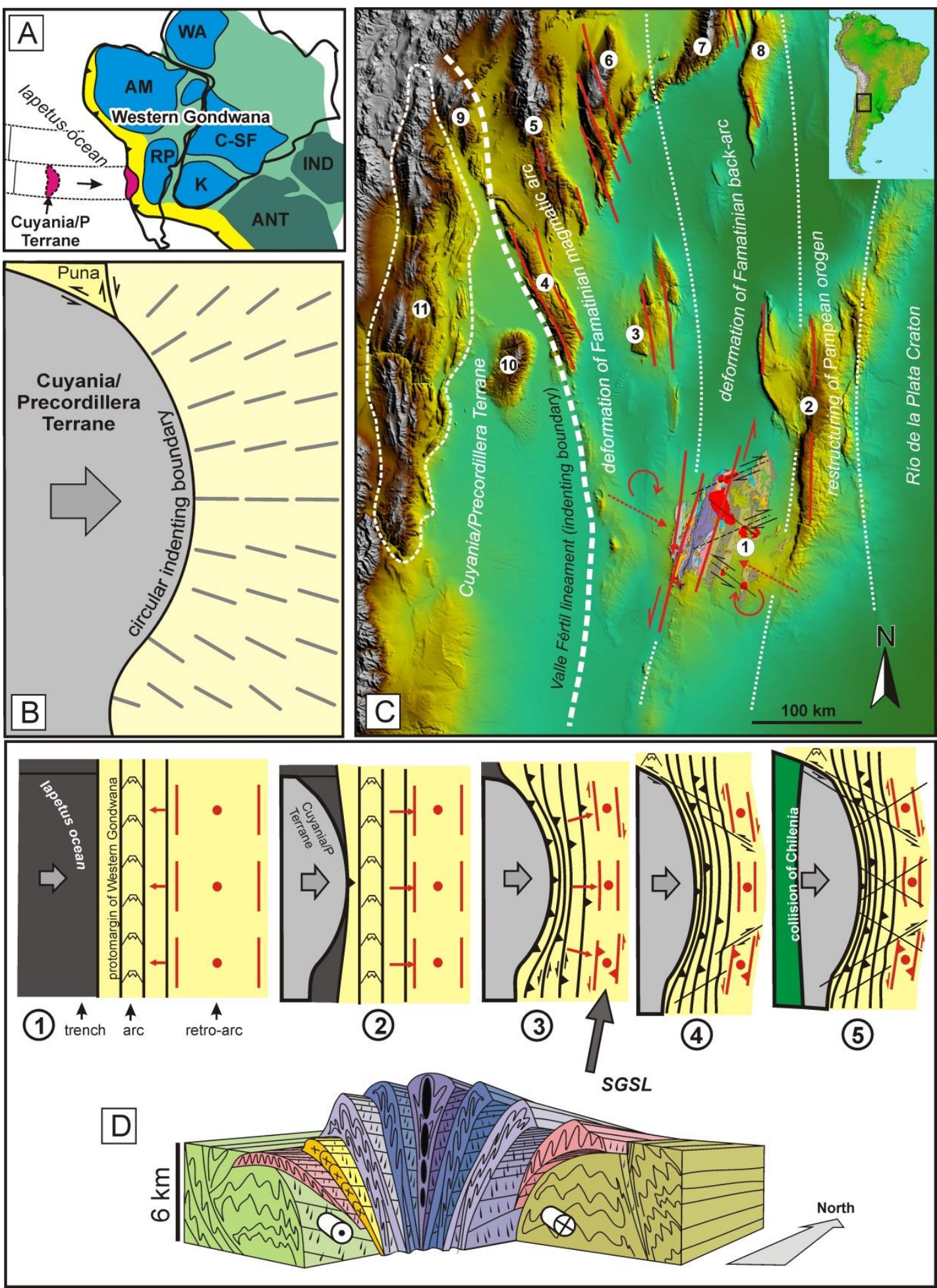
Fig. 14: Geotectonic interpretation. a) Location of the Cuyania/Precordillera terrain in the proto-margin of Western Gondwana. The western part of the orogenic Terra Australis is shown in yellow (modified from Cawood, 2005). The acronyms correspond to the different cratons that made up Gondwana: AM-Amazonia, ANT-Antartica, C-SF-Congo-Sao Francisco, IND_-India, K-Kalahari, RP-Rio de la Plata, WA-West Africa. b) Radial distribution of the horizontal deviatoric stresses generated by a hypothetical sub-circular morphology of the Cuyania/Precordillera terrane. c) Red lines indicate the general directions of the ductile structures associated with the collision of Cuyania/Precordillera in different parts of the Famatinian orogen. 1) Sierra de San Luis, 2) Sierras de Córdoba, 3) Chepes and Ulapes ranges, 4) Sierra de Valle Fértil 5) Sierra de Famatina, 6) Sierra de Velasco, 7) Sierra de Ambato, 8) Sierra de Ancasti, 9) Umango and Maz ranges, 10) Sierra de Pie de Palo, 11) Precordillera. d) Sketch of the deformation stages in the collisional Famatinian edge due to an indenter with subcircular morphology. The red lines and points allow visualizing the rotation that structures have suffered during the collision in the SGSL. 1) Rectilinear subduction zone that develops a volcanic arc and extension in an ensialic back-arc (slab roll back); (2) the geotectonic regime goes from extensional to compressional in the back-arc, the sedimentary sequences fold and metamorphose (huge crustal shortening); 3) rotation of the collided margin due to indentation of Cuyania. In the SGSL the rotation was clockwise allowing the development of the shear system that produced the double-vergent transpressive belt (extrusion of the PMC); 4) towards the end of the indentation, a large-scale set of strike-slip ductile faults with NE direction were developed in the SGSL (dextral tectonic escape); 5) Finally, a conjugate NE-SW and NW-SE system of ductile faults was generated conditioning the emplacement style of the postorogenic plutons, probably related to the collision of the Chilenia terrane over the recently collided edge of Gondwana.

\section{Conclusions}

The 3-dimensional geological and geophysical inversion model presented in this study provides essential insights into the geometry of southern Sierra Grande de San Luis. Our results are compatible with a large-scale doubly-vergent structure covering predominantly the Pringles Metamorphic Complex and the San Luis Formation. This is supported by the morphology of the different lithological units, their metamorphic conditions, and the interaction of the structural elements. A vertical extrusion of metamorphic rocks occurred, where the hanging wall corresponded to the Pringles Metamorphic Complex and the footwall corresponded to the San Luis Formation. In this area, the Nogolí and Conlara Metamorphic Complexes formed the external basement blocks that compressed the mega structure. Evidence for this is the opposite sense of movement on both flanks of the large-scale structure and the high magnetic values in the shear zones, possibly caused by plastic deformation. Furthermore, the high magnetic values associated with the presence of ultramafic bodies indicate that there was a potential window towards lower levels of the crust and a connection to the mantle allowing the entry of mafic-ultramafic material into the core of the pop-up structure.

The most likely mechanism responsible for the geometry of southern Sierra Grande de San Luis is the collision of Cuyania/Precordillera. This terrane acted as an indenter (microcontinent) with a convex morphology, conditioning the style of deformation on the Western Gondwana margin in the analysed area. Currently, the results of this can be seen in the style 
of ductile deformation zones along the entire Famatinian deformation belt from Northwest Argentina to the Sierra Grande de San Luis. In these areas, vertically reverse shear zones and lateral movement (strike-slip) determined different shortening directions. For the modelled zone, a clockwise rotation of the horizontal deviatoric stress vectors resulted in a convergent non-coaxial movement with a minor sinistral component during the progressive deformation of the shear zone s. Since inverse modelling of potential-field data is inherently non-unique, we want to emphasize the importance of seeking new evidence to help improve the proposed extrusion model and its tectonic history in order to understand thoroughly the regional geodynamic context.

\section{Acknowledgements}

We are grateful to Universidad Nacional Del Sur, Instituto Geofísico Sismológico Volponi, Grosso Group Company and Servicio Geológico Minero (SEGEMAR) for the permission to use the geophysical data for academic purposes. We would like to acknowledge Intrepid Geophysics for the Geomodeller software academic license, Consejo Nacional de Investigaciones Científicas y Técnicas (CONICET) for their research grant, and P-3-2-0114 (UNSL), PROIPRO 3-1718 (UNSL), PICT-2014-0958, PDTS No A77/2015-CS CICITCASECIT, PIO 150-201501-00039-CO CONICET-SECIT projects and Departamento de Geofísica y Astronomía (UNSJ) for covering the financial costs. The authors are also thankful for the thorough review of the manuscript by Dr. Victor Ramos, an anonymous reviewer and the Editor in Chief Dr. Zheng-Xiang Li.

\section{References}

Allmendinger, R.W., Cardozo, N.C., Fisher, D., 2013. Structural Geology Algorithms: Vectors \& Tensors: Cambridge, England, Cambridge University Press, 289 pp.

Astini, R.A. and Dávila F.M., 2004. Ordovician back arc foreland and Ocloyic thrust belt development on the western Gondwana margin as a response to Precordillera terrane accretion. Tectonics, 23, TC4008, DOI:10.1029/2003TC001620.

Barazangi, M. and Isacks, B.L., 1976. Spatial distribution of earthquakes and subduction of the Nazca Plate beneath South America. Geology, 4, 686-692.

Benedetto, J.L., 2004. The allochthony of the Argentine Precordillera ten years later (1993-2003): A new paleobiogeographic test of the microcontinental model. Gondwana Research, 7, 1027-1039. 
Bense, F., Costa, C., Oriolo, S., Löbens, S., Dunkl, I., Wemmer, K., Siegesmund, S., 2017. Exhumation history and landscape evolution of the Sierra de San Luis (Sierras Pampeanas, Argentina) - new insights from low - temperature thermochronological data. Andean Geology 44 (3): 275-306.

Best, M.G., 2003. Igneous and Metamorphic Petrology, 729 pp. Oxford Blackwell Science.

Blakely, R.J., 1995. Potential Theory in Gravity \& Magnetic Applications. 441 pp. Cambridge University Press. ISBN: 052141508X.

Brogioni, N., 2001. Geología de los cuerpos Virorco y El Fierro, faja máfica-ultramáfica del borde oriental de la Sierra de San Luis. Revista de la Asociación Geológica Argentina, 56 (3), 281-292.

Calcagno, P., Chiles, J.P., Courrioux, G., Guillen, A., 2008. Geological modelling from field data and geological knowledge Part I. Modelling method coupling 3D potential-field interpolation and geological rules. Physics of the Earth and Planetary Interiors 171, 147-157.

Caminos, R., 1979. Sierras Pampeanas Noroccidentales. Salta, Tucumán, Catamarca, La Rioja y San Juan. In: Turner J.C.M., (Ed.), Geología Regional Argentina, Academia Nacional de Ciencias, 225291, Córdoba.

Cardozo, N. and Allmendinger, R.W., 2013. Spherical projections with OSXStereonet: Computers \& Geosciences, v. 193-205, DOI: 10.1016/j.cageo.2012.07.021.

Casquet, C., Baldo, E., Galindo, C. Pankhurst, R.J., Rapela, C.W., Fanning, M.C., 2014. Las vulcanitas de la Formación San Luis (Sierra de San Luis, Argentina): Nueva edad (SHRIMP) y geoquímica isotópica ( $\mathrm{Sr}$ - Nd). 18 Congreso Geológico Argentino, Actas, S21-8, Córdoba.

Cawood, P.A. 2005. Terra Australis Orogen: Rodinia breakup and development of the Pacific and Iapetus margins of Gondwana during the Neoproterozoic and Paleozoic. Earth-Science Reviews 69, 249-279.

Chernicoff, C.J. and Ramos, V.A., 2003. El basamento de la Sierra de San Luis: nuevas evidencias magnéticas y sus implicancias tectónicas. Revista de la Asociación Geológica Argentina, 58(4), 511 524.

Christiansen, R. O., Rodriguez, A., Martinez, P., Lince Klinger, F., 2015. Avances en el tratamiento estadístico de datos gravimétricos de las sierras de San Luis y Comechingones. importancia del grillado en procesamientos posteriores. Geoacta, 40(2), 76-86.

Clark, D. A. 1997. Magnetic petrophysics and magnetic petrology: aids to geological interpretation of magnetic surveys. AGSO Journal of Australian Geology and Geophysics, 17, 83-104.

Costa, C., Gardini, C., Chiesa, J., Ortiz Suárez, A., Ojeda, G., Rivarola, D., Tognelli, G., Strasser, E., Carugno Durán, A., Guerstein, P., Sales, D., Vinciguerra, 2001a. Hoja Geológica 3366-III San Luis, provincias de San Luis y Mendoza. Instituto de Geología y Recursos Minerales, Servicio Geológico-Minero Argentino (SEGEMAR), Boletín Nº 293, pp 104, en CD, ISSN No 1667 1988.

Costa C., C. Gardini, A. Ortiz Suarez, J. Chiesa, G. Ojeda, D. Rivarola, E. Strasser, P. Morla, J. Ulacco, G. Tognelli, A. Carugno Durán, H. Vinciguerra y D. Sales, 2001b. Hoja Geológica 3366I, San Francisco del Monte de Oro. Provincias de San Luis, Mendoza y San Juan. Instituto de Geología y Recursos Minerales, Servicio Geológico Minero Argentino. Boletín 278, p. Buenos Aires.

Cristofolini, E.A., Otamendi, J.E., Ducea, M.N., Pearson, P.N., Tibaldi, A.M., Baliani, I., 2012. Detrital zircon U-Pb ages of metasedimentary rocks from Sierra de Valle Fértil: Entrapment of Middle 
and Late Cambrian marine successions in the deep roots of the Early Ordovician Famatinian arc. Journal of South American Earth Sciences, 37, 77-94.

Cristofolini, E.A., Otamendi, J.E., Walker Jr., B.A., Tibaldi, A.M., Armas, P., Bergantz, G.W., Martino, R.D., 2014. A Middle Paleozoic shear zone in the Sierra de Valle Fértil, Argentina: Records of a continent-arc collision in the Famatinian margin of Gondwana. Journal of South American Earth Sciences, 56, 170-185.

Cristofolini, E.A., Otamendi, J.E., Martino, R.D., Tibaldi, A.M., Armas, P., Barzola, M., 2017. Faja de cizalla Las Lajas: petrografía, estructura interna e implicancias tectónicas, extremo sur de la Sierra de Comechingones, Provincias de Córdoba y San Luis. Revista de la Asociación Geológica Argentina 74 (3): 295-314.

Cruciani, G., Franceschelli, M., Brogioni, N., 2012. Early stage evolution of the mafic-ultramafic belt at La Melada, Sierra de San Luis, Argentina: P-T constraints from metapyroxenite pseudosection modelling. Journal of South American Earth Sciences, 37, 1-12.

Delakowitz, B., Höll, R., Hack, M., Brodtkorb, M., Stärk, H., 1991. Geological and geochemical studies of the Sierra del Morro-Oeste (San Luis Province, Argentina): meta-sediments and metavolcanics from a probable back-arc setting. Journal of South American Earth Sciences, 4, 189-200.

Delpino, S., Dimieri, L., Bjerg, E., Kostadinoff, J., Mogessie, A., Hoinkes, G., Hauzenberger, Ch., Felfernig, A., 2001. Geometrical analysis and timing of structures on mafic-ultramafic bodies and high-grade metamorphic rocks, Sierras Grandes of San Luis, Argentina. Journal of South American Earth Science, 14(1), 101-112.

Delpino, S., Bjerg, E., Ferracutti, G., Mogessie, A., 2007. Counterclockwise tectonometamorphic evolution of the Pringles Metamorphic Complex, Sierras Pampeanas of San Luis (Argentina). Journal of South American Earth Sciences, 23, 147-175.

Delpino, S., Rueda, M., Urraza., I., Grasemann, B., 2016. Microstructural development in ductile deformed metapelitic-metapsamitic rocks: A case study from the greenschist to granulite facies megashear zone of the Pringles Metamorphic Complex, Argentina. In: Mukherjee, S., Mulchrone, K.F (Eds), Ductile Shear Zones: From micro- to macro-scales, First Edition. Ltd. Published 2016 by John Wiley \& Sons, Ltd., 224-248.

Drobe, M., López de Luchi, M.G., Steenken, A., Frei, R., Naumann, R., Wemmer, K., Siegesmund., 2009. Provenance of the Late Proterozoic to Early Cambrian metaclastic sediments of the Sierra de San Luis (Eastern Sierras Pampeanas) and Cordillera oriental, Argentina. Journal of South American Earth Sciences, 28, 239-262.

Drobe, M., López de Luchi, M.G., Steenken, A., Wemmer, K., Naumann, R., Frei, R., Siegesmund., 2011. Geodynamic evolution of the Eastern Sierras Pampeanas (Central Argentina) based on geochemical, $\mathrm{Sm}-\mathrm{Nd}, \mathrm{Pb}-\mathrm{Pb}$ and SHRIMP data. Int J Earth Sci (Geol Rundsch), 100, 631657.

Ducea, M. N., Otamendi, J. E., Bergantz, G., Stair, K. M., Valencia, V. A., Gehrels, G. E., 2010. Timing constraints on building an intermediate plutonic arc crustal section: $\mathrm{U}-\mathrm{Pb}$ zircon geochronology of the Sierra Valle Fértil-La Huerta, Famatinian arc, Argentina. Tectonics, 29(4).

Gibson, H., Sumpton, J., Fitzgerald, D., Seikel, R. 2013. 3D modelling of geology and gravity data: summary workflows for minerals exploration. East Asia: Geology, Exploration Technologies and Mines-Bali. 
González, P.D, Sato, A.M., Llambías, E.J., Basei., M.A.S., Vlanch, S., 2004. Early Paleozoic structural and metamorphic evolution of western Sierra de San Luis, in relation to the accretion of Cuyania. Gondwana Research, 7, 1157-1170.

Guillen Antonio, Calcagno Philippe, Courrioux Gabriel, Joly Aurore, Ledru Patrick, 2008. 3D realistic modelling of geology from field data and geological knowledge, part II - modelling validation using of gravity and magnetic data inversion. Physics of the Earth and Planetary Interiors $171,158-169$.

Gutscher, M., Spakman, W., Bijwaard, H., Engdahl, E., 2000. Geodynamics of flat subduction: Seismicity and tomographic constraints from the Andean margin. Tectonics, 19(5), 814-833.

Hauzenberger, C., Mogessie, A., Hoinkes, G., Felfernig, A., Bjerg, E., Kostadinoff, J., Delpino, S., Dimieri, L., 2001. Metamorphic evolution of the Sierras de San Luis, Argentina: granulites facies metamorphism related to mafic intrusions. Mineralogy and Petrology, 71, 95-126.

Hinze, W.J., 2003. Bouguer reduction density, why 2.67?. Geophysics, 68(5), 1559-1560.

Höckenreiner, M., Söllner, F., Miller, H., 2003. Dating the TIPA shear zone: an Early Devonian terrane boundary between the Famatinian and Pampean systems (NW Argentina). Journal of South American Earth Sciences, 16, 45-66.

Isles, D. J., and Rankin, L. R. 2013. Geological interpretation of aeromagnetic data. Perth: Australian Society of Exploration Geophysicists.

Jacobsen, B. H. 1987. A case for upward continuation as a standard separation filter for potentialfield maps. Geophysics, 52(8), 1138-1148.

Kane, M.F., 1962. A comprehensive system of terrain corrections using a digital computer. Geophysics, 27(4), 455-462.

Kostadinoff J., Bjerg E.A., Delpino S., Dimieri L., Mogessie A., Hoinkes G., Hauzenberger C., Felfernig A., 1998. Gravimetric and magnetometric anomalies in the Sierras Pampeanas of San Luis. Revista de la Asociación Geológica Argentina, 53(4), 549-552.

LaFehr, T.R., 1991a. Standardization in gravity reduction. Geophysics, 56(8), 1170-1178.

LaFehr, T.R., 1991b. An exact solution for the gravity curvature (Bullard B) correction. Geophysics, 56(8), 1179-1184.

Larrovere, M.A., Alasino, P.H., Baldo, E.G., 2016. La Faja de cizalla dúctil doble-vergente del noroeste de la Sierra de Velasco: deformación de la corteza media durante la orogenia Famatiniana. Revista de la Asociación Geológica Argentina, 73(1), 117-133.

Llambías, E.J. and Malvicini, L., 1982. Geología y génesis de los yacimientos de tungsteno de las Sierras del Morro, Los Morrillos y Yulto, provincia de San Luis. Revista de la Asociación Geológica Argentina, 37, 100-143.

Llambías, E., Sato, A.M., Ortiz Suárez, A., Prozzi, C., 1998. The granitoids of the sierra de San Luis. Geological Society of London. Special Publication No 142. In: Pankhurst, R.J., Rapela, C.W., (eds), The Proto-Andean Margin of Gondwana. Geological Society, London, Special Publication, 142, 325-341.

López de Luchi, M.G., Cerredo, M.E., Siegesmund, S., Steenken, A., Wemmer, K., 2003. Provenance and tectonic setting of the protoliths of the metamorphic complexes of Sierra de San Luis. Revista de la Asociación Geológica Argentina, 58(4), 525-540. 
López de Luchi, M.G, Siegesmund, S., Wemmer, K., Steenken, A., Naumann, R., 2007. Geochemical constraints on the petrogenesis of the Paleozoic granitoids of the Sierra de San Luis, Sierras Pampeanas, Argentina. Journal of South American Earth Sciences, 24, 138-166.

López de Luchi, M.G., Martínez Dopico, C.I., Wemmer, K., Siegesmund, S., 2017. Untangling the Neoproterozoic-Early Paleozoic Tectonic Evolution of the Eastern Sierras Pampeanas Hidden in the Isotopical Record. In: Siegesmund S., Basei M., Oyhantçabal P., Oriolo S. (eds) Geology of Southwest Gondwana. Regional Geology Reviews. Springer, Cham, 433-466.

Martino, R.D., 2003. Las fajas de deformación dúctil de las Sierras Pampeanas de Córdoba: una reseña general. Revista de la Asociación Geológica Argentina, 58: 549-571.

McClay, K. and Bonora, M., 2001. Analog models of restraining stepovers in strike-slip fault systems. The American Association of Petroleum Geologists, 85 (2), 233-260.

McInerney, P., Guillen, A., Courrioux, G., Calcagno, P., Lees, T., 2005. Building 3D geological models directly from the data? A new approach applied to Broken Hill, Australia. US Geological Survey Open-File Report, 1428, 119-130.

Morosini, A., Ortiz Suárez, A., 2011. El Metamorfismo de contacto del Granito La Escalerilla, en el área de La Carolina. San Luis, Argentina. Revista de la Asociación Geológica Argentina, 68 (2): 277289.

Morosini, A., Ortiz Suárez, A., 2013. Inversión metamórfica asociada al emplazamiento de granitos sincolisionales en la sierra de San Luis. $11^{\circ}$ Congreso de Mineralogía y Metalogenia. Universidad Nacional de San Juan. Acta 1: 321-326. San Juan.

Morosini, A., Enriquez, E., Ortiz Suárez, A., Ramos, G., Carugno Durán, A., Ulacco, J., 2014. Hipótesis de extrusión vinculada a la inversión metamórfica del Complejo Metamórfico Pringles, Sierra de San Luis. $19^{\circ}$ Congreso Geológico Argentino, Actas, S21-38, Córdoba.

Morosini, A., Ortiz Suárez, A., Otamendi, J., Pagano, D., Ramos, G., 2017. La Escalerilla pluton, San Luis Argentina: The orogenic and post-orogenic magmatic evolution of the famatinian cycle at Sierras de San Luis. Journal of South American Earth Sciences, 73, 100-118.

Nagy, D., 1966. The gravitational attraction of a right rectangular prism. Geophysics, 31(2), 362-371.

Naudy, H., and Dreyer, H. 1968. Non-linear filtering applied to aeromagnetic profiles. Geophysical Prospecting, 16(2), 171-178.

Oldenburg, D. W., Pratt, D. A., Milkereit, B. 2007. Geophysical inversion for mineral exploration: A decade of progress in theory and practice. In Proceedings of exploration (Vol. 7, No. 5, pp. 61-95).

Ortiz Suárez, A., 1988. El basamento de Las Aguadas, provincia de San Luis. Revista de la Asociación Argentina de Mineralogía, Petrología y Sedimentología, 19(1-4), 13-24.

Ortiz Suárez, A., 1999. Geología y petrología del área de San Francisco del Monte de Oro, San Luis. Ph.D. thesis. Facultad de Ciencias Físico-Matemáticas y Naturales, Universidad Nacional de San Luis. (unpublished).

Ortiz Suárez, A., Prozzi, C., Llambías, E., 1992. Geología de la parte Sur de la Sierra de San Luis y granitoides asociados, Argentina. Revista de estudios geológicos, 48, 269-277.

Ortiz Suárez, A. and Casquet, M. C., 2005. Inversión metamórfica en el orógeno famatiniano de la Sierra de San Luis, Argentina. Geogaceta, 38, 231-234. 
Otamendi, J.E., Vujovich, G.I., de la Rosa, J.D., Castro, A., Tibaldi, A., Martino, R., Pinotti, L., 2009. Geology and petrology of a deep crustal zone the Famatinian paleoarc, Sierras Valle Fértil - La Huerta, San Juan, Argentina. Journal of South American Earth Sciences, 27, 258-279.

Prozzi, C. and Ramos, G., 1988. La formación San Luis. I Jornadas de Trabajo de Sierras Pampeanas. San Luis. Actas 1, San Luis.

Ramos, G. and Ortiz Suárez, A., 2005. Edad de la mineralización de wolframio del Valle de Pancanta y su implicancia en la evolución del magmatismo de la región. En Aceñolaza et al. (eds.). Simposio Bodenbender. INSUGEO Serie Correlación Geológica 19: 113-122, Tucumán.

Ramos, V.A., 2004. Cuyania, an exotic block to Gondwana: review of a historical success and the present problems. Gondwana Research 7, 1009-1026.

Ramos, V.A., Cristallini, E.O., Pérez, D.J., 2002. The Pampean flat-slab of the Central Andes. Journal of South American Earth Sciences, 15, 59-78.

Rapela, C.W., Pankhurst, R.J., Baldo, E., Casquet, C., Galindo, C., Fanning, C.M., Saavedra, J., 2001. Ordovician metamorphism in the Sierras Pampeanas: new U-Pb SHRIMP ages in central-east Valle Fértil and the Velasco Batholith. Revista Comunicaciones Edición especial, $3^{\circ}$ South American Symposium on isotope geology, Servicio Nacional de Geología y Minería, Abbreviated Abstracts: 165. CD: $616-619$, Santiago.

Rapela, C.W., Verdecchia, S.O., Casquet, C., Baldo, E,G., Galindo, C., Murra, J.A., Dahlquist, J.A., 2015. Identifying Laurentian and SW Gondwana sources in the Neoproterozoic to Early Paleozoic metasedimentary rocks of the Sierras Pampeanas: Paleogeographic and tectonic implications. Gondwana Research, 32, 193-212.

Sato, A.M., González, P.D., Llambías, E.J., 2003. Evolución del orógeno Famatiniano en la Sierra de San Luis: magmatismo de arco, deformación y metamorfismo de bajo a alto grado. Revista de la Asociación Geológica Argentina, 58(4), 487-504.

Schwartz, J. J., Gromet, L. P., Miro, R. 2008. Timing and duration of the calc-alkaline arc of the Pampean Orogeny: implications for the Late Neoproterozoic to Cambrian evolution of Western Gondwana. The Journal of Geology, 116(1), 39-61.

Semenov, I. and Weinberg, R.F., 2017. A major mid-crustal decollement of the Paleozoic convergent margin of western Gondwana: The Guacha Corral shear zone, Argentina. Journal of Structural Geology, 103, 75-99.

Siegesmund, S., Steenken, A., López de Luchi, M.G., Wemmer, K., Hoffmann, A., Mosch, S., 2004. The Las Chacras-Potrerillos batholith (Pampean Ranges, Argentina): structural evidences, emplacement and timing of the intrusion. Int J Earth Sci (Geol Rundsch), 93, 23-43.

Siegesmund, S., Steenken, A., Martino, R.D., Wemmer, K., López de Luchi, M.G., Frei, R., Guereschi, A., 2010. Time constraints on the tectonic evolution of the Eastern Sierras Pampeanas (Central Argentina). International Journal of Earth Sciences, 99(6), 1199-1226.

Sims, J.P., Stuart-Smith, P.G., Lyons, P., Skirrow, R.G., 1997. Report on 1:250.000 scale Geological and Metallogenic Maps, Sierras de San Luis and Comechingones. Prov. of San Luis and Córdoba. Geoscientific mapping of the Sierras Pampeanas Argentine-Australian Cooperative Project. Unpublished Report.

Sims, J., Ireland, T., Camacho, A., Lyons, P., Pieters, P., Skirrow, R., Stuart-Smith, P., Miró, R., 1998. $\mathrm{U}-\mathrm{Pb}$, Th- $\mathrm{Pb}$ and $\mathrm{Ar}-\mathrm{Ar}$ geochronology from the southern Sierras Pampeanas, Argentina: implications for the Paleozoic tectonic evolution of the western Gondwana margin. In: Pankhurst, R.J., 
Rapela, C.W., (eds), The Proto-Andean Margin of Gondwana. Geological Society, London, Special Publication, 142, 256-281.

Simpson, C., Law, R.D., Gromet, L.P., Miró, R., Northrup, C.J., 2003. Paleozoic deformation in the Sierras de Cordoba and Sierra de Las Minas, eastern Sierras Pampeanas, Argentina. Journal of South American Earth Sciences, 15, 749-764.

Smithson, S.B., 1971. Densities of metamorphic rocks. Geophysics, 36(4), 690-694.

Spagnuolo, C.M., Rapalini, A.E., Astini, R.A., 2011. Reinterpretation of the Ordovician rotations in NW Argentina and Northern Chile: a consequence of the Precordillera collision?. Int J Earth Sci (Geol Rundsch), 100, 603-618. DOI 10.1007/s00531-010-0578-2

Sruoga, P., Ibañes, O.D., Japas, M.S., Urbina, N.D., 2017. El Morro caldera ( $33^{\circ} 10^{\prime}$ S, $66^{\circ} 24^{\prime}$ W), San Luis, Argentina: An exceptional case of fossil pre-collapse updoming. Journal of Volcanology and Geothermal Research, Volume 337, 81-97.

Steenken, A., Siegesmund, S., López de Luchi, M.G., Frei, R., Wemmer, K., 2006. Neoproterozoic to early Palaeozoic events in the Sierra de San Luis: implications for the Famatinian geodynamics in the Eastern Sierras Pampeanas (Argentina). Journal of the Geological Society, 163, 965-982.

Steenken, A., Siegesmund, S., Wemmer, K., López de Luchi, M.G., 2008. Time constraints on the Famatinian and Achalian structural evolution of the basement of the Sierra de San Luis (Eastern Sierras Pampeanas, Argentina). Journal of South American Earth Sciences, 25(3), 336-358.

Steenken, A., López de Luchi, M.G., Martínez Dopico, C., Drobe, M., Wemmer, K., Siegesmund, S., 2010. The Neoproterozoic-early Paleozoic metamorphic and magmatic evolution of the Eastern Sierras Pampeanas: an overview. International Journal of Earth Sciences, 1-24 pp., DOI:10.1007/s00531-010-0624-0.

Thomas, W.A. and Astini, R.A., 1996. The Argentine precordillera: a traveler from the Ouachita embayment of North American Laurentia. Science, 273(5276), 752-757.

Verdecchia, S.O., Collo, G., Zandomeni, P.S., Wunderlin, C., Fehrmann, M., 2018. Crystallochemical indexes and geothermobarometric calculations as a multiproxy approach to P-T condition of the low-grade metamorphism: The case of the San Luis Formation, Eastern Sierras Pampeanas of Argentina. Lithos, 324-325, 385-401.

von Gosen, W., 1998a. Transpressive deformation in the southwestern part of the Sierras de San Luis (Sierras Pampeanas, Argentina). Journal of South American Earth Sciences, 11(3), 233-264.

von Gosen, W., 1998b. The Phyllite and Micaschist Group with associated intrusions in the Sierras de San Luis (Sierras Pampeanas/Argentina) - structural and metamorphic relations. Journal of South American Earth Sciences, 11(1), 79-109.

von Gosen, W. and Prozzi, C., 1998. Structural Evolution of the Sierra de San Luis (Eastern Sierras Pampeanas, Argentina): implications for the proto-andean Margin of Gondwana. In: Pankhurst, R.J., Rapela, C.W., (eds), The Proto-Andean Margin of Gondwana. Geological Society, London, Special Publication, 142, 235-258.

von Gosen, W. and Prozzi, C., 2005. Deformation of an Early Paleozoic magmatic arc related to terrane collision: Sierra de San Luis (Eastern Sierras Pampeanas, Argentina), Neues Jahrb. Geol. Palaeontol. Abh., 238(1), 107-160. 
Whitmeyer, S.J. and Simpson, C., 2004. Regional deformation of the Sierra de San Luis, Argentina: Implications for the Paleozoic development of western Gondwana. Tectonics, 23, 1-16. DOI: 10.1029/2003TC001542.

Zaffarana C., Geuna S., Poma S., Patiño D.A., 2011. Reassessment of the volume of the Las Aguilas mafic-ultramafic intrusives, San Luis, Argentina, based on an alternative geophysical model. Journal of South American Earth Sciences, 32(3), 183-195.

Zavala, C., Prozzi, C., Freije, H., 2000. Hallazgo de facies contorníticas en el Proterozoico tardío Paleozoico temprano de las Sierras Pampeanas, Argentina. II Congreso Latinoamericano de Sedimentología y VIII RAS. Actas: 187-188, Mar del Plata.

Zeng, H., Xu, D., Tan, H., 2007. A model study for estimating optimum upward-continuation height for gravity separation with application to a Bouguer gravity anomaly over a mineral deposit, Jilin province, northeast China. Geophysics, 72(4), I45-I50. 


\begin{tabular}{|c|c|c|c|c|c|c|c|c|c|}
\hline$\frac{\text { Table 1. S }}{\text { Sher }}$ & & & & & $\triangle \mathrm{ACO}$ & 르 $D / A$ & 1080 & $P$ & \\
\hline 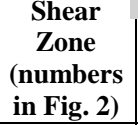 & $\begin{array}{c}\text { Extension } \\
\text { length / width }\end{array}$ & Rock & $\begin{array}{l}\text { Smy-foliation } \\
\text { strike / dip }\end{array}$ & $\begin{array}{l}\text { Lmy- } \\
\text { lineation } \\
\text { dip dir. / dip }\end{array}$ & Sense of shear zone & $\begin{array}{l}\text { Deformation } \\
\text { conditions }\end{array}$ & $\begin{array}{l}\text { Age of deformation } \\
\text { and method }\end{array}$ & Protolith & Characteristics \\
\hline $\begin{array}{l}\text { Realito - } \\
\text { Río de La } \\
\text { Quebrada } \\
\text { (1) }\end{array}$ & $\begin{array}{l}82 \mathrm{~km} / \\
\sim 500 \mathrm{~m} \text { (for } \\
\text { each branch) }\end{array}$ & $\begin{array}{l}\text { phyllonites, } \\
\text { mylonites, } \\
\text { protomylonites }\end{array}$ & $\begin{array}{l}\sim \mathrm{N} 15^{\circ} / \sim 88^{\circ} \mathrm{W} \\
\text { (northern part) } \\
\sim \mathrm{N} 25^{\circ} / \\
65^{\circ}-80^{\circ} \mathrm{NW} \\
\text { (central part) } \\
\sim \mathrm{N} 20^{\circ} / \\
58^{\circ}-70^{\circ} \mathrm{SE} \\
\text { (southern part) }\end{array}$ & $\begin{array}{l}\sim 270^{\circ} / 80^{\circ} \\
\text { (northern part } \\
\sim 340^{\circ} / 40^{\circ} \\
\text { (central part) } \\
\sim 120^{\circ} / 45^{\circ} \\
\text { (southern part) }\end{array}$ & $\begin{array}{l}\begin{array}{l}\text { reverse-dextral } \\
\text { (northern part) }\end{array} \\
\text { reverse-sinistral } \\
\text { (central and southern } \\
\text { part) }\end{array}$ & $\begin{array}{l}\sim 550^{\circ}-450^{\circ} \mathrm{C} \\
\text { amphibolites to } \\
\text { greenschist facies }\end{array}$ & $\begin{array}{l}\sim 472 \mathrm{Ma} \text { (a) } \\
\mathrm{U} / \mathrm{Pb} \text {-zircon in syn- } \\
\text { kinematic } \\
\text { tonalites } \\
\text { (field evidences) } \\
\\
\sim 379 \mathrm{Ma} \text { (h) K/Ar- } \\
\text { muscovite } \\
\text { (in pegmatite) }\end{array}$ & $\begin{array}{l}\text { migmatites, schists, } \\
\text { phyllites, tonalities, } \\
\text { granodiorites, } \\
\text { granites, pegmatites }\end{array}$ & $\begin{array}{l}\text { It ramifies in several smaller anastomosed strips and it is intercepted } \\
\text { by lateral branches. It is an emplacement zone of tonalitic and } \\
\text { granodioritic bodies. It has three parts with distinctive features from } \\
\text { north to south. Separates the NMC from the SLF and the PMC. In the } \\
\text { northern section, located in the east edge of the Realito pluton, von } \\
\text { Gosen and Prozzi (2005) called this shear zone "Las Vizcacheras". }\end{array}$ \\
\hline $\begin{array}{l}\text { Pancanta } \\
- \\
\text { La } \\
\text { Carolina } \\
(2)\end{array}$ & $\begin{array}{l}38 \mathrm{~km} / \\
\sim 200 \mathrm{~m} \\
\text { (main branch) } \\
\\
5 \mathrm{~km} / \\
\sim 100 \mathrm{~m} \\
\text { (secondary } \\
\text { branch) }\end{array}$ & $\begin{array}{l}\text { phyllonites, } \\
\text { mylonites }\end{array}$ & $\begin{array}{l}\sim \mathrm{N} 25^{\circ} / \sim 80 \mathrm{NW} \\
\text { (main branch) } \\
\sim \mathrm{N} 85^{\circ} / \sim 77^{\circ} \mathrm{N} \\
\text { (secondary } \\
\text { branch) }\end{array}$ & $\begin{array}{l}\sim 220^{\circ} / \sim 30^{\circ} \\
(\text { main branch) } \\
\sim 280^{\circ} / \sim 50^{\circ} \\
\text { (secondary } \\
\text { branch) }\end{array}$ & $\begin{array}{l}\text { reverse-dextral to } \\
\text { dextral strike-slip } \\
\text { (both branches) }\end{array}$ & $\begin{array}{l}\sim 350^{\circ}-450^{\circ} \mathrm{C} \\
\text { greenschists facies } \\
\text { (slaty cleavage } \\
\text { microstructure are } \\
\text { common) }\end{array}$ & $\begin{array}{l}\sim 468 \mathrm{Ma}(\mathrm{b}) \\
\text { U/Pb-zircon in the } \\
\text { Bemberg syn- } \\
\text { kinematic tonalite } \\
\sim 432 \mathrm{Ma} \mathrm{(c)} \mathrm{K} / \mathrm{Ar}- \\
\text { muscovite in a } \\
\text { quartz-vein }\end{array}$ & $\begin{array}{l}\text { schists, phyllites, } \\
\text { tonalities, gabbros }\end{array}$ & $\begin{array}{l}\text { It has two branches. It is related to scheelite-bearing veins that are } \\
\text { located in the Pancanta Valley. The main branch is located within the } \\
\text { SLF, while the secondary branch separates the SLF from the NMC. }\end{array}$ \\
\hline $\begin{array}{l}\text { La } \\
\text { Escalerill } \\
\text { a (3) }\end{array}$ & $\begin{array}{l}63 \mathrm{~km} / \\
\sim 400 \mathrm{~m} \\
\text { (main branch) } \\
\sim 7 \mathrm{~km} / \sim 30 \mathrm{~m} \\
\text { (synthetic } \\
\text { branches) }\end{array}$ & $\begin{array}{l}\text { phyllonites, } \\
\text { mylonites }\end{array}$ & $\begin{array}{l}\sim \mathrm{N} 10^{\circ} / \sim 65^{\circ} \mathrm{E} \\
\text { (average of main } \\
\text { branch) } \\
\\
\sim \mathrm{N} 345^{\circ} / \\
\sim 80^{\circ} \mathrm{SW} \text { or } \mathrm{NE} \\
\text { (synthetic } \\
\text { branches) }\end{array}$ & $\begin{array}{l}\sim 155^{\circ} / \sim 50^{\circ} \\
\text { (main branch) } \\
\sim 5^{\circ} / \sim 155 \\
\text { (synthetic } \\
\text { branches) }\end{array}$ & $\begin{array}{l}\begin{array}{l}\text { reverse-sinistral } \\
\text { (main branch) }\end{array} \\
\text { sinistral strike-slip } \\
\text { (synthetic branches) }\end{array}$ & $\begin{array}{l}\sim 500^{\circ} \mathrm{C} \\
\text { amphibolites facies } \\
\text { greenschist facies } \\
\text { (retrograde } \\
\text { deformation) }\end{array}$ & $\begin{array}{l}\sim 477 \mathrm{Ma}(\mathrm{d}) \\
\mathrm{U} / \mathrm{Pb}-\mathrm{zircon} \text { in the } \\
\text { La Escalerilla syn- } \\
\text { kinematic granite. } \\
\\
\sim 414 \mathrm{Ma}(\mathrm{e}) \\
\mathrm{Rb} / \mathrm{Sr}-\mathrm{WR} \text { and } ~ 366 \\
\mathrm{Ma} \text { (b) Ar/Ar- } \\
\text { muscovite } \\
\text { (reactivations) }\end{array}$ & \begin{tabular}{|l} 
schists, \\
granites
\end{tabular} & $\begin{array}{l}\text { In the central part, it intersects several minor NNW trending synthetic } \\
\text { branches with sinistral strike-slip movement. It separates the El } \\
\text { Volcán and the La Escalerilla plutons from the western belt of the } \\
\text { Micachists Group (PMC). }\end{array}$ \\
\hline $\begin{array}{l}\text { San Pedro } \\
- \\
\text { El Volcán } \\
\text { (4) }\end{array}$ & $\begin{array}{l}93 \mathrm{~km} / \\
\sim 300 \mathrm{~m}\end{array}$ & mylonites & $\sim \mathrm{N} 10^{\circ} / \sim 7$ & $\begin{array}{l}\sim 160^{\circ} / \sim 60^{\circ} \\
\text { (south stretch) } \\
\sim 280^{\circ} / 5^{\circ} \\
\text { (north end) }\end{array}$ & $\begin{array}{l}\text { reverse-sinistral } \\
\text { (south stretch) } \\
\text { dextral strike-slip } \\
\text { (north end) }\end{array}$ & $\begin{array}{l}\sim 500-450^{\circ} \mathrm{C} \\
\text { amphibolites facies }\end{array}$ & $\begin{array}{l}\sim 428 \mathrm{Ma}(\mathrm{f}) \\
\mathrm{Pb} / \mathrm{Pb} \text {-staurolite } \\
\sim 375 \mathrm{Ma}(\mathrm{b}) \mathrm{K} / \mathrm{Ar}- \\
\text { muscovite }\end{array}$ & $\begin{array}{l}\text { migmatites, } \\
\text { gneisses, schists, } \\
\text { pegmatites, } \\
\text { amphibolites }\end{array}$ & $\begin{array}{l}\text { It separates the western belt of the MG from the SJC. At the northern } \\
\text { end a later ductile fault displaced and curved the meridian trace of } \\
\text { this shear zone (with dextral strike-slip motion). It is consequence of } \\
\text { the tectonic escape, and was named by von Gosen and Prozzi (2005) } \\
\text { as "San Pedro Shear Zone" (stricto sensu). }\end{array}$ \\
\hline $\begin{array}{l}\text { La } \\
\text { Arenilla } \\
(5)\end{array}$ & $\begin{array}{l}105 \mathrm{~km} / \\
400 \mathrm{~m} \text { to } \\
3 \mathrm{~km} \text { (depends } \\
\text { on the branch) }\end{array}$ & $\begin{array}{l}\text { mylonites, } \\
\text { ultramylonites }\end{array}$ & $\begin{array}{l}\sim \mathrm{N} 12^{\circ} />70^{\circ} \mathrm{E} \\
\text { or }>70^{\circ} \mathrm{W} \\
\text { (depends on the } \\
\text { branch) }\end{array}$ & $\begin{array}{l}290^{\circ} \text { or } 110^{\circ} / \\
>70^{\circ} \text { (depends } \\
\text { on the branch) }\end{array}$ & $\begin{array}{l}\text { reverse-sinistral } \\
\text { (general movement), } \\
\text { some ramifications } \\
\text { have dextral strike- } \\
\text { slip movement }\end{array}$ & $\begin{array}{l}>500^{\circ} \mathrm{C} \\
\text { upper amphibolites } \\
\text { facies } \\
\text { (initial conditions } \\
\text { of deformation) }\end{array}$ & $\begin{array}{l}\sim 446 \mathrm{Ma}(\mathrm{g}) \\
\text { K/Ar-hornblende } \\
\text { (in amphibolite } \\
\text { mylonite) } \\
\\
\sim 402 \mathrm{Ma}(\mathrm{h}) \mathrm{K} / \mathrm{Ar}- \\
\text { muscovite } \\
\text { (in syn-kinematics } \\
\text { pegmatites) }\end{array}$ & $\begin{array}{l}\text { migmatites, } \\
\text { gneisses, } \\
\text { mafic-ultramafic } \\
\text { rocks, } \\
\text { pegmatites }\end{array}$ & $\begin{array}{l}\text { It is an internal shear zone of the SJC, branched into several smaller } \\
\text { arms. In the thinnest sector of the SJC, it shows as a single wide belt } \\
(\sim 3 \mathrm{~km}) \text {, while to the north and south it branches into several belts of } \\
\text { lower width. Within it mafic-ultramafic rocks are distributed in } \\
\text { rosary-shape along the La Jovita-Las Águilas mafic-ultramafic belt. }\end{array}$ \\
\hline
\end{tabular}




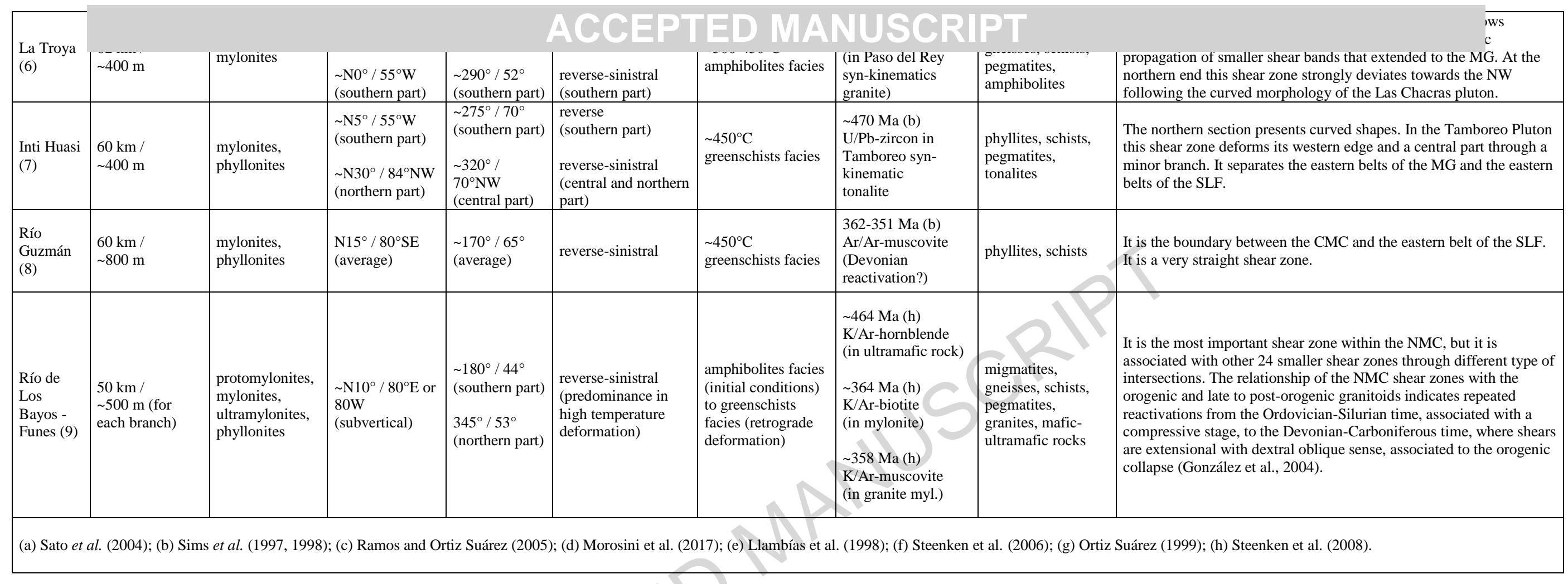


Table 2 Description of the density samples

\begin{tabular}{|c|c|c|c|c|c|c|c|c|}
\hline Sation & Latitude & Longitude & Lithology & $\begin{array}{c}\text { Mean Dens. } \\
{\left[\mathrm{g} / \mathrm{cm}^{3}\right]}\end{array}$ & Samples & SD & Min & Max \\
\hline 56 & -32.98427 & -66.214626 & Gabbro & 2.83 & 4 & NIA & NIA & NIA \\
\hline 58 & -32.983439 & -66.218882 & Gabbro & 2.90 & 4 & NIA & NIA & NIA \\
\hline $265 c$ & -33.063684 & -66.250675 & Gabbro & 3.04 & 4 & NIA & NIA & NIA \\
\hline 317-tinaj & -33.016164 & -66.214542 & Tonalite & 2.87 & 4 & NIA & NIA & NIA \\
\hline $\mathrm{P} 024$ & -32.7168804 & -66.1612034 & Migmatite & 2.81 & 5 & 0.006 & 2.80 & 2.82 \\
\hline $\mathrm{P} 026$ & -32.7503973 & -66.1492927 & Granite & 2.55 & 5 & 0.017 & 2.52 & 2.57 \\
\hline $\mathrm{P} 026 \mathrm{~b}$ & -32.7503973 & -66.1492927 & MUM rock & 2.92 & 5 & 0.022 & 2.88 & 2.94 \\
\hline P029 & -32.8186479 & -66.0958969 & Phyllite & 2.63 & 5 & 0.056 & 2.56 & 2.71 \\
\hline $\mathrm{P} 030$ & -32.8466459 & -66.1059298 & Granite & 2.56 & 5 & 0.025 & 2.53 & 2.59 \\
\hline $\mathrm{P} 031$ & -32.8785111 & -66.1138933 & Phyllite & 2.62 & 5 & 0.016 & 2.59 & 2.63 \\
\hline $\mathrm{P} 032$ & -32.8975076 & -66.1113894 & Tonalite & 2.72 & 5 & 0.035 & 2.68 & 2.77 \\
\hline $\mathrm{P} 033$ & -32.9144998 & -66.0847866 & Migmatite & 2.50 & 5 & 0.049 & 2.43 & 2.55 \\
\hline $\mathrm{P} 034$ & -32.9374582 & -66.0826323 & Schists & 2.76 & 5 & 0.026 & 2.72 & 2.79 \\
\hline $\mathrm{P} 036$ & -32.9422759 & -66.0656168 & Amphibolite & 3.03 & 5 & 0.048 & 2.99 & 3.11 \\
\hline P037 & -32.9243464 & -66.0549991 & Gneiss & 2.65 & 5 & 0.027 & 2.61 & 2.67 \\
\hline P038 & -32.9314256 & -66.0391098 & Schist & 2.55 & 5 & 0.032 & 2.50 & 2.58 \\
\hline $\mathrm{P} 040$ & -32.9370291 & -65.9852606 & Schist & 2.53 & 5 & 0.038 & 2.49 & 2.58 \\
\hline P041 & -32.9287901 & -65.9431733 & Schist & 2.56 & 5 & 0.051 & 2.46 & 2.59 \\
\hline P042 & -32.9406186 & -65.9243397 & Phyllite & 2.53 & 5 & 0.011 & 2.50 & 2.53 \\
\hline P044 & -32.9544982 & -65.8688154 & Schist & 2.63 & 5 & 0.014 & 2.60 & 2.64 \\
\hline P045 & -32.9787116 & -65.8461324 & Schist & 2.58 & 5 & 0.026 & 2.55 & 2.61 \\
\hline P046 & -32.9971754 & -65.8121961 & Migmatite & 2.59 & 4 & 0.045 & 2.53 & 2.63 \\
\hline $\mathrm{P} 047$ & -33.0137863 & -65.7746522 & Schist & 2.56 & 5 & 0.174 & 2.25 & 2.67 \\
\hline $\mathrm{P} 048$ & -33.0222583 & -65.7354013 & Schist & 2.65 & 5 & 0.031 & 2.62 & 2.68 \\
\hline P049 & -33.0280309 & -65.6956849 & Schist & 2.64 & 4 & 0.016 & 2.61 & 2.64 \\
\hline $\mathrm{P} 050$ & -33.0460478 & -65.6635053 & Schist & 2.63 & 5 & 0.022 & 2.59 & 2.64 \\
\hline P055 & -32.9790937 & -65.6254182 & Schist & 2.54 & 5 & 0.027 & 2.51 & 2.58 \\
\hline $\mathrm{P} 056$ & -32.9451133 & -65.6368699 & Schist & 2.60 & 4 & 0.040 & 2.55 & 2.64 \\
\hline $\mathrm{P} 057 \mathrm{~V}$ & -32.9410242 & -65.6745917 & Latite & 2.46 & 5 & 0.024 & 2.42 & 2.48 \\
\hline $\mathrm{P} 058$ & -32.9276129 & -65.7107832 & Schist & 2.65 & 5 & 0.019 & 2.61 & 2.66 \\
\hline P059 & -32.8949868 & -65.721922 & Schist & 2.67 & 4 & 0.008 & 2.66 & 2.68 \\
\hline P060 & -32.8664301 & -65.7450295 & Migmatite & 2.59 & 5 & 0.028 & 2.54 & 2.62 \\
\hline P062 & -32.8143468 & -65.8251987 & Schist & 2.68 & 2 & 0.024 & 2.65 & 2.69 \\
\hline P063 & -32.8304266 & -65.8585006 & Phyllite & 2.53 & 5 & 0.014 & 2.51 & 2.54 \\
\hline P064 & -32.8420485 & -65.8918955 & Latite & 2.51 & 5 & 0.020 & 2.47 & 2.53 \\
\hline P066 & -32.8097742 & -65.9900011 & Gneiss & 2.57 & 5 & 0.033 & 2.53 & 2.60 \\
\hline P067 & -32.7896643 & -66.055045 & Quartzite & 2.49 & 5 & 0.053 & 2.41 & 2.54 \\
\hline P068 & -32.7937369 & -66.0694888 & Latite & 2.31 & 5 & 0.051 & 2.26 & 2.39 \\
\hline PN18 & -33.1437222 & -65.8932778 & Schist & 2.71 & 5 & NIA & NIA & NIA \\
\hline $\mathrm{PN} 23$ & -33.1193056 & -65.9184444 & Schist & 2.56 & 5 & NIA & NIA & NIA \\
\hline
\end{tabular}




\begin{tabular}{|l|c|c|l|c|c|c|c|c|}
\hline \multicolumn{1}{|c|}{ Sation } & Latitude & Longitude & \multicolumn{1}{|c|}{ Lithology } & $\begin{array}{c}\text { Mean } \\
\text { Dens.[g/cm } \mathbf{c}^{3}\end{array}$ & Samples & SD & Min & Max \\
\hline PN23b & -33.1193056 & -65.9184444 & Pegmatite & 2.65 & 6 & NIA & NIA & NIA \\
\hline PN33 & -33.0955556 & -65.9927778 & Granite & 2.44 & 5 & NIA & NIA & NIA \\
\hline PN35 & -33.1026944 & -66.0118889 & Schist & 2.53 & 5 & NIA & NIA & NIA \\
\hline PN44 & -33.0580556 & -66.0755556 & Mylonite & 2.97 & 5 & NIA & NIA & NIA \\
\hline PN47 & -33.0624722 & -66.0909722 & Amphibolite & 2.95 & 5 & NIA & NIA & NIA \\
\hline PN55 & -33.0381111 & -66.1528611 & Schist & 2.38 & 5 & NIA & NIA & NIA \\
\hline PN57 & -33.0381111 & -66.1723611 & Granite & 2.57 & 5 & NIA & NIA & NIA \\
\hline PN60 & -33.0164444 & -66.1927222 & Granite & 2.67 & 5 & NIA & NIA & NIA \\
\hline PN61 & -33.0115278 & -66.2039167 & Granite & 2.40 & 5 & NIA & NIA & NIA \\
\hline PN63 & -32.9924722 & -66.2052778 & Tonalite & 2.44 & 5 & NIA & NIA & NIA \\
\hline PN68 & -32.9720556 & -66.251000 & Gneiss & 2.51 & 5 & NIA & NIA & NIA \\
\hline PN72 & -32.9396111 & -66.2661111 & Granite & 2.77 & 4 & NIA & NIA & NIA \\
\hline PS18 & -33.2748056 & -66.159500 & Schist & 2.77 & 4 & NIA & NIA & NIA \\
\hline PS21a & -33.2398056 & -66.179750 & Pegmatite & 2.39 & 5 & NIA & NIA & NIA \\
\hline PS21b & -33.2398056 & -66.179750 & Granite & 2.49 & 5 & NIA & NIA & NIA \\
\hline PS26 & -33.2086111 & -66.2370556 & Granite & 2.41 & 5 & NIA & NIA & NIA \\
\hline PS29 & -33.1807778 & -66.2650833 & Granite & 2.72 & 4 & NIA & NIA & NIA \\
\hline
\end{tabular}


Table 3 Description of the magnetic susceptibility samples

\begin{tabular}{|c|c|c|c|c|c|c|c|c|}
\hline Station & Latitude & Longitude & Lithology & Mean Susc. [SI] & Samples & SD & $\operatorname{Min}$ [SI] & $\operatorname{Max}$ [SI] \\
\hline PN47 & -33.06247 & -66.09097 & Amphibolite & 0.00070 & 5 & NIA & NIA & NIA \\
\hline P062 & -32.81435 & -65.82520 & Schist & 0.00021 & 5 & 0.000029 & 0.00018 & 0.00024 \\
\hline P044 & -32.95450 & -65.86882 & Schist & 0.00008 & 5 & 0.000054 & 0.00003 & 0.00015 \\
\hline P047 & -33.01379 & -65.77465 & Schist & 0.00025 & 5 & 0.000049 & 0.00019 & 0.00030 \\
\hline $\mathrm{P} 048$ & -33.02226 & -65.73540 & Schist & 0.00035 & 5 & 0.000047 & 0.00030 & 0.00040 \\
\hline $\mathrm{P} 056$ & -33.94511 & -65.63687 & Schist & 0.00045 & 5 & 0.000249 & 0.00018 & 0.00078 \\
\hline $\mathrm{P} 058$ & -32.92761 & -65.71078 & Schist & 0.00027 & 5 & 0.000068 & 0.00018 & 0.00035 \\
\hline $\mathrm{P} 057$ & -32.94102 & -65.67459 & Schist & 0.00065 & 5 & 0.000249 & 0.00037 & 0.00090 \\
\hline P049 & -33.02803 & -65.69568 & Schist & 0.00019 & 5 & 0.000070 & 0.00010 & 0.00027 \\
\hline P059 & -32.89499 & -65.72192 & Schist & 0.00031 & 5 & 0.000094 & 0.00020 & 0.00042 \\
\hline $\mathrm{P} 050$ & -33.04605 & -65.66351 & Schist & 0.00029 & 5 & 0.000149 & 0.00013 & 0.00042 \\
\hline $\mathrm{P} 063$ & -32.83043 & -65.85850 & Phyllite & 0.00009 & 5 & 0.000043 & 0.00005 & 0.00014 \\
\hline P029 & -32.81865 & -66.09590 & Phyllite & 0.00017 & 5 & 0.000036 & 0.00012 & 0.00021 \\
\hline $\mathrm{P} 034$ & -32.93746 & -66.08263 & Gneiss & 0.00027 & 5 & 0.000152 & 0.00010 & 0.00046 \\
\hline $\mathrm{P} 037$ & -32.95277 & -66.06947 & Gneiss & 0.00013 & 5 & 0.000017 & 0.00011 & 0.00015 \\
\hline PS5 & -33.24286 & -65.92869 & Gneiss & 0.00030 & 5 & NIA & NIA & NIA \\
\hline PS3 & -33.22958 & -65.88117 & Gneiss & 0.00033 & 5 & NIA & NIA & NIA \\
\hline PS2 & -33.20789 & -65.87317 & Gneiss & 0.00063 & 5 & NIA & NIA & NIA \\
\hline PN57 & -33.03811 & -66.17236 & Granite & 0.00004 & 5 & NIA & NIA & NIA \\
\hline PS21 & -33.23981 & -66.17975 & Granite & 0.00020 & 5 & NIA & NIA & NIA \\
\hline PS27 & -33.19958 & -66.24917 & Granite & 0.00020 & 5 & NIA & NIA & NIA \\
\hline PN60 & -33.01644 & -66.19272 & Granite & 0.00020 & 5 & NIA & NIA & NIA \\
\hline PN72 & -32.93961 & -66.26611 & Granite & 0.00040 & 5 & NIA & NIA & NIA \\
\hline $\mathrm{P} 026$ & -32.75040 & -66.14929 & Granite & 0.00004 & 5 & 0.000013 & 0.00002 & 0.00005 \\
\hline $\mathrm{P} 030$ & -32.84665 & -66.10593 & Granite & 0.00008 & 5 & 0.000020 & 0.00000 & 0.00010 \\
\hline $\mathrm{P} 025$ & -32.74338 & -66.16239 & Granite & 0.00010 & 5 & 0.000046 & 0.00006 & 0.00016 \\
\hline P038 & -32.93143 & -66.03911 & MUM rock & 0.00059 & 5 & 0.000210 & 0.00041 & 0.00084 \\
\hline $\mathrm{P} 067$ & -32.78966 & -66.05505 & Schist & 0.00017 & 5 & 0.000042 & 0.00013 & 0.00021 \\
\hline $\mathrm{P} 041$ & -32.92879 & -65.94317 & Schist & 0.00023 & 5 & 0.000050 & 0.00018 & 0.00030 \\
\hline $\mathrm{P} 040$ & -32.93703 & -65.98526 & Schist & 0.00013 & 5 & 0.000070 & 0.00004 & 0.00019 \\
\hline $\mathrm{P} 046$ & -32.99718 & -65.81220 & Migmatite & 0.00023 & 5 & 0.000075 & 0.00013 & 0.00031 \\
\hline $\mathrm{P} 023$ & -32.69044 & -66.14831 & Migmatite & 0.00052 & 5 & 0.000393 & 0.00021 & 0.00083 \\
\hline $\mathrm{P} 027$ & -32.76456 & -66.11832 & Migmatite & 0.00021 & 5 & 0.000073 & 0.00013 & 0.00030 \\
\hline P024 & -32.71688 & -66.16120 & Migmatite & 0.03049 & 5 & 0.011848 & 0.01333 & 0.04054 \\
\hline P065 & -32.82419 & -65.93814 & Migmatite & 0.00013 & 5 & 0.000077 & 0.00008 & 0.00024 \\
\hline P066 & -32.80977 & -65.99000 & Migmatite & 0.00010 & 5 & 0.000048 & 0.00006 & 0.00017 \\
\hline $\mathrm{P} 060$ & -32.86643 & -65.74503 & Migmatite & 0.00016 & 5 & 0.000069 & 0.00007 & 0.00021 \\
\hline $\mathrm{P} 045$ & -32.97871 & -65.84613 & Migmatite & 0.00028 & 5 & 0.000125 & 0.00017 & 0.00045 \\
\hline PN67 & -32.97628 & -66.24217 & Schist & 0.00001 & 5 & NIA & NIA & NIA \\
\hline PS19 & -33.26300 & -66.16736 & Schist & 0.00003 & 5 & NIA & NIA & NIA \\
\hline PS26 & -33.20861 & -66.23706 & Granite & 0.00003 & 5 & NIA & NIA & NIA \\
\hline
\end{tabular}




\begin{tabular}{|c|c|c|c|c|c|c|c|c|}
\hline Station & Latitude & Longitude & Lithology & Mean Susc. [SI] & Samples & SD & $\operatorname{Min}[\mathrm{SI}]$ & $\operatorname{Max}[\mathrm{SI}]$ \\
\hline PN24 & -33.12267 & -65.92883 & Schist & 0.00003 & 5 & NIA & NIA & NIA \\
\hline PN38 & -33.08708 & -66.03636 & Schist & 0.00003 & 5 & NIA & NIA & NIA \\
\hline PN61 & -33.01153 & -66.20392 & Tonalite & 0.00004 & 5 & NIA & NIA & NIA \\
\hline PN18 & -33.14372 & -65.89328 & Migmatite & 0.00007 & 5 & NIA & NIA & NIA \\
\hline PN12 & -33.19797 & -65.85358 & Schist & 0.00009 & 5 & NIA & NIA & NIA \\
\hline PN10 & -33.20972 & -65.82389 & Migmatite & 0.00010 & 5 & NIA & NIA & NIA \\
\hline PN37 & -33.08803 & -66.02517 & Schist & 0.00010 & 5 & NIA & NIA & NIA \\
\hline PN68 & -32.97206 & -66.25100 & Schist & 0.00010 & 5 & NIA & NIA & NIA \\
\hline PN69 & -32.96589 & -66.25844 & Schist & 0.00010 & 5 & NIA & NIA & NIA \\
\hline PN70 & -32.95753 & -66.26197 & Schist & 0.00010 & 5 & NIA & NIA & NIA \\
\hline PN44 & -33.05806 & -66.07556 & Gneiss & 0.00020 & 5 & NIA & NIA & NIA \\
\hline PS30 & -33.18697 & -66.26989 & Granite & 0.00022 & 5 & NIA & NIA & NIA \\
\hline PN41 & -33.09653 & -66.06247 & Gneiss & 0.00023 & 5 & NIA & NIA & NIA \\
\hline PS29 & -33.18078 & -66.26508 & Granite & 0.00024 & 5 & NIA & NIA & NIA \\
\hline PN26 & -33.13294 & -65.94542 & Schist & 0.00028 & 5 & NIA & NIA & NIA \\
\hline PN22 & -33.12050 & -65.90800 & Schist & 0.00030 & 5 & NIA & NIA & NIA \\
\hline PN33 & -33.09556 & -65.99278 & Mylonite & 0.00250 & 5 & NIA & NIA & NIA \\
\hline P042 & -32.94062 & -65.92434 & Mudstone & 0.00016 & 5 & 0.000046 & 0.00011 & 0.00022 \\
\hline PN35 & -33.10269 & -66.01189 & Schist & 0.00001 & 5 & NIA & NIA & NIA \\
\hline PS18 & -33.27481 & -66.15950 & Schist & 0.00002 & 5 & NIA & NIA & NIA \\
\hline $\mathrm{P} 032$ & -32.89751 & -66.11139 & Tonalite & 0.00029 & 5 & 0.000108 & 0.00014 & 0.00038 \\
\hline PN63 & -32.99247 & -66.20528 & Tonalite & 0.00040 & 5 & NIA & NIA & NIA \\
\hline P064 & -32.84205 & -65.89190 & Latite & 0.00096 & 5 & 0.000930 & 0.00022 & 0.00217 \\
\hline $\mathrm{P} 031$ & -32.87851 & -66.11389 & Granite & 0.00014 & 5 & 0.000039 & 0.00009 & 0.00018 \\
\hline $\mathrm{P} 033$ & -32.91450 & -66.08479 & Schist & 0.00028 & 5 & 0.000102 & 0.00013 & 0.00037 \\
\hline P039 & -32.95125 & -66.00713 & Granite & 0.00035 & 5 & 0.000074 & 0.00026 & 0.00044 \\
\hline $\mathrm{P} 043$ & -32.92942 & -65.90137 & Phyllite & 0.00033 & 5 & 0.000072 & 0.00024 & 0.00041 \\
\hline P061 & -32.81770 & -65.78592 & Schist & 0.00024 & 5 & 0.000165 & 0.00006 & 0.00044 \\
\hline
\end{tabular}

